\title{
Assessment of building damages and adaptation options under extreme flood scenarios in Shanghai
}

\author{
Jiachang Tu ${ }^{1,2}$, Jiahong Wen ${ }^{1 *}$, Liang Emlyn Yang ${ }^{2 *}$, Andrea Reimuth ${ }^{2}$, Stephen S. Young ${ }^{3}$, Min Zhang ${ }^{1}$,
} Luyang Wang ${ }^{1}$, Matthias Garschagen ${ }^{2}$

$5 \quad{ }^{1}$ School of Environmental and Geographical Science, Shanghai Normal University, 200234 Shanghai, China

${ }^{2}$ Department of Geography, Ludwig Maximilian University of Munich (LMU), 80333 Munich, Germany

${ }^{3}$ Geography and Sustainability Department, Salem State University, 01970 Salem, USA

Correspondence to: J. Wen (jhwen@shnu.edu.cn), L.E. Yang (emlyn.yang@1mu.de)

Abstract. Plenty of various measures have been taken to mitigate flood losses in Shanghai over thousands of years, including

10 the construction of sea dikes and floodwalls. However, the combined effects of intensified rainstorms, sea-level rise, land subsidence, and rapid urbanization are exacerbating extreme flood risks and potential flood losses in the fast-developing coastal city. In light of these changes, this article presents an assessment of possible exposure and damage losses of buildings in Shanghai (including residential, commercial, workplace, and industrial buildings). Based on extreme flood scenarios caused by storm surges, precipitation, and fluvial floods, current flood-defence standards will soon be overtaken. Further analyses

15 show that the inundation area could reach $9 \%, 16 \%, 24 \%$, and $49 \%$ of Shanghai (excluding the area of islands) under the 1/200, 1/500, 1/1000, and 1/5000-year flooding scenarios, respectively. This study finds, in terms of the total building damage, the 1/5000-year flood scenario damage is more than ten times the 1/200-year flood scenario. Accordingly, the average annual loss (AAL) of residential, commercial, office, and industrial buildings are 13.9, 2.3, 5.3, and 3.9 million USD. Specifically, among the 15 (non-island) districts in Shanghai, Pudong has the highest exposure and AAL at all the four flood scenarios, while the inner city (including seven districts) is also subject to extreme AAL of up to $40 \%$ of its total building values. This study further addresses the possibilities of these extreme flood scenarios, and adaptation options such as: strategic urban planning, advanced building protections, and systematic flood management. Conclusions of the study provide information for scenario-based decision making and cost-benefit analysis for extreme flood risk management in Shanghai and is applicable to other similar coastal megacities.

\section{Introduction}

Coastal cities that have historically suffered from major flood impacts, such as: Dhaka, Guangzhou, Miami, Mumbai, New Orleans, and New York, are heavily affected by future rising flood risks to their population and assets (Woetzel et al., 2020a; Nguyen et al., 2021; Chan et al., 2021). By 2050, over 570 low-lying coastal cities and their 800 million inhabitants will face risks from the impacts of floods and rising sea levels, causing economic losses of up to 1 trillion USD (C40Cities, 2018).

30 Frequent floods will also accelerate stresses of water supply (Yang et al., 2013), health care (Paterson et al., 2018), basin 
management (Yang et al., 2018a), infrastructure maintenance (Yang, 2020; Bubeck et al., 2019), and ecosystem degradation (Tonkin et al., 2018).

Although many coastal cities are facing increasing flood risks (Liang et al., 2017), some will be more seriously affected than others due to local climate change effects, high exposure, or limited adaptation capacities. One of the hotspots, which is facing high flood risks already, is Shanghai. Compared to other coastal cities, like Dhaka, Manila, and Rotterdam, Shanghai is the most vulnerable city to flooding (Balica et al., 2012). Coupled with factors of human (population exposure and property exposure) and environmental (low-lying land, land subsidence problems, the threat of sea-level rise, frequent typhoons and extreme precipitation) relationships, Shanghai is ranked as one of the top 20 cities to flooding in the world (Hallegatte et al., 2013; Wu et al., 2019). As an answer to this obstacle, Shanghai, the most developed financial centre in China, should increasingly install flood protection, with a focus on hard measures.

Since the 1950s, hard measures, like seawalls (along the Yangtze River Estuary and Hangzhou Bay) and levees (along the Huangpu River), were constructed in Shanghai (Zhou et al., 2017). However, the seawalls and levees can be easily destroyed due to the lower structures and standards during the various stages of construction (Zhou et al., 2017). Only 23\% of seawalls can withstand a 200-year flooding scenario; $58 \%$ of seawalls can withstand a 100 -year flooding scenario while the rest of seawalls withstand less than a 100-year flooding scenario (Wang et al., 2012). The present protection level of the levees along the Huangpu River for the lowest sections, according to the study, is around 1/50-year flooding scenario (Ke et al., 2018). Meanwhile, the historical crest heights in the Huangpu River reveals a significant growing trend from 1950 to 2000, with the existing levees failing several times and leading to extreme damage (Ke et al., 2018), posing a greater threat to Shanghai. Overall, to protect Shanghai from a future failure of floodwalls and levees, extreme flood scenarios, and their consequences

50 should be the taken as the first step of an integrative risk assessment.

Reviewing the current literature shows that various flood scenarios have been widely developed and validated for measuring flood risks in Shanghai. For example, according to the trend of relative sea level rise and the harmonic analysis of storm surges along the Shanghai coast, Yin et al. (2011) forecasts flood scenarios in 2030 and 2050. One two-dimensional MIKE 21 flow model has been applied in simulating future combined effects (sea level rise, land subsidence, and storm surges) of flood scenarios in 2030, 2050, and 2100 (Wang et al., 2012). Fluvial floods from the Huangpu River were also simulated, considering land subsidence, sea level rise, and storm tide, in considering the return periods of 20,50,100, 200, 500, and 1000 years in Shanghai, respectively (Yin et al., 2013). Incorporated with three anthropogenic variables (land subsidence, urbanization, and flood defence), Yin et al. (2015) used a numerical 2D modelling approach for return periods of 10, 100, and 1000 years. In general, the flood scenarios produced in most existing studies tended to focus on the possible future flood scenario changes rather than extreme events, e.g., the concern floods over a 1000-year return period.

The previous studies are dedicated to simulating floods or flooding in Shanghai instead of focusing on the overall risks. The consequences of flooding (i.e., construction damage), however, should be taken into consideration. Flood damage to buildings is noticeably a large part of the total flood losses in cities (Chmutina et al., 2014; Park and Won, 2019), in addition to the often devastating human costs (Woetzel et al., 2020a). In 1997, Typhoon Winnie caused large-scale floods in Shanghai and affected 
more than 5000 households (Du et al., 2020). In 2008, floods damaged 160 streets and 13,000 residential buildings in Shanghai. Therefore, local communities and governmental departments are increasingly calling for holistic analyses of possible building damage under extreme flood scenarios in order to accurately understand and assess potential flood impacts (Kelman and Spence, 2004). Accurate loss data play an integral role in assessing the damages of buildings. But obtaining accurate data is a challenge shared in many areas (Middelmann-Fernandes, 2010), especially in assessing the damage of buildings. To estimate building stocks and the values at risk under a 1/1000-year extreme flood scenario, Wu et al. (2019) integrate census-level building floor-area data and geo-coded building asset value data. Shan et al. (2019) further assessed the flood losses of residential buildings and household properties in Shanghai based on a stage-damage function, building footprint, and housing prices. Mostly, deeper investigations into the uncertainties (e.g., asset values, damage rate, and flood process) with reliance on flood risks and damages of buildings (e.g., residential, commercial, office, and industrial) are also urgently needed in order to better support decision making which enhances the overall flood resiliency of the city.

To address these questions, we adopted the very extreme flood scenarios with return periods of 200, 500, 1000, and 5000 years. The four extreme flood scenarios are assumed as integrative effects of multiple flood-triggering factors, such as typhooninduced storm surge, precipitation, fluvial flood in combination with a high astronomical tide, to reflect low probability-high impact flood situations in Shanghai. The objective of this paper is to assess flood losses of residential, commercial, office, and industrial buildings under extreme flood scenarios in Shanghai. To achieve the objective, we modeled building exposures at four extreme flood scenarios with return periods of 1/200, 1/500, 1/1000, and 1/5000, respectively. Combining the exposure maps with the stage-damage functions, the study evaluated and identified the spatial distribution of losses for the specific types of buildings in Shanghai. Section 2 of the paper introduces the data and details of the methods, and section 3 presents the data analysis and major results of the study. Section 4 discusses future flood scenarios and proper adaptation strategies for building a flood-resilient Shanghai. Final conclusions are described in section 5.

\section{Data and Methods}

\subsection{Study Area}

Shanghai is the biggest coastal city in China in terms of population (24.3 million in 2019) and is the major trading and financial hub of China. The city has an area of $6340.5 \mathrm{~km}^{2}$ that lies in the Yangtze River Delta along the northern edge of Hangzhou Bay (Figure 1). Shanghai is prone to flooding because of its flat low-lying terrain, as well as its location on the path of frequent typhoons from the northwest Pacific (Balica et al., 2012). Moreover, the city experienced an average land subsidence of 1.97 meter from 1921 to 2007 and the trend is continuing (Gong and Yang, 2008) additionally driving flood risks (Quan, 2014). In addition, the total building area in Shanghai reached $1368.8 \mathrm{~km}^{2}$ (SMBS, 2018) which includes residential buildings (686.5 $\left.\mathrm{km}^{2}\right)$, commercial buildings $\left(81.6 \mathrm{~km}^{2}\right)$, workplace buildings $\left(90 \mathrm{~km}^{2}\right)$, industrial buildings $\left(283 \mathrm{~km}^{2}\right)$, and others. The total construction industry value is 159.8 billion USD (SMBS, 2018). 


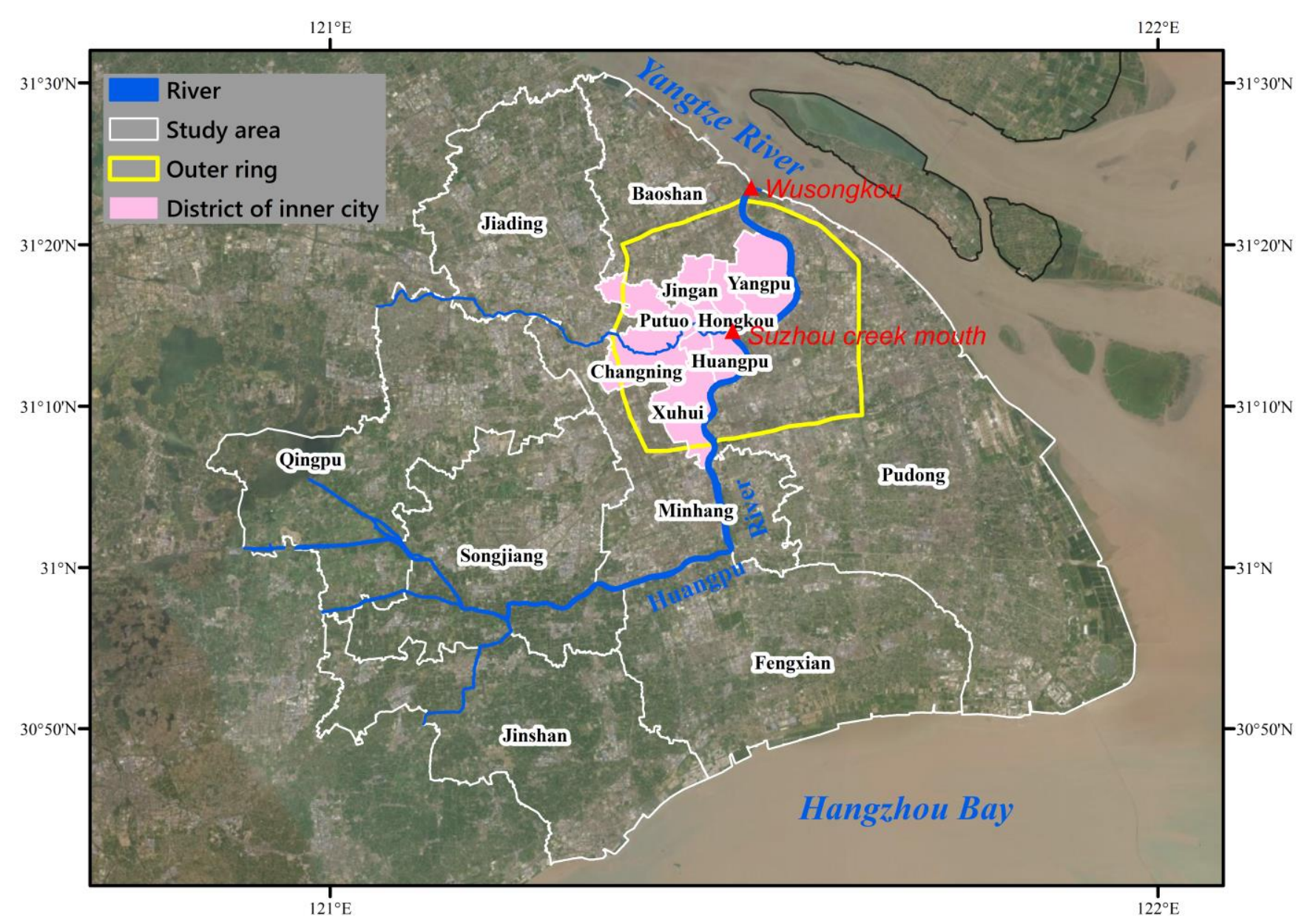

Figure 1. Satellite image-based map of the study area (Shanghai's 15 districts, excluding the city's islands) (The satellite image background is from Esri).

\subsection{Data}

100 The study involves the data of four extreme flood scenarios, building maps, land use and land cover data, and the construction costs of different buildings in Shanghai. In this study, we adopted the very extreme flood scenarios with return periods of 200, 500, 1000, and 5000 years. Based on the extreme water levels for different return periods, the hydrodynamic modelling is composed of atmospheric models (Fujita typhoon model), ocean models (TOMAWAC, TELEMAC), and coastal models (MIKE 1D/2D), developed to simulate four extreme flood scenarios, respectively combined with a fluvial flood during

105 Typhoon Winnie in 1997 (Wang et al., 2019). Typhoon Winnie brought the highest recorder water level with 5.72 meters since 1900, which caused the collapse of 148 meters of floodwalls and overflowed $57 \mathrm{~km}$ of floodwalls and $69 \mathrm{~km}$ of sea dikes. The rainfall and river discharge data based on Typhoon Winnie in 1997 are superimposed on coastal flood simulations. These four flood scenarios are raster data with a 60 -meter spatial resolution. 
The data for Shanghai's buildings were acquired from Baidu Map (Baidu Maps, 2017) using a python-based web crawler, and then processed with ArcGIS software. Baidu Maps provide various map services, such as satellite images, street maps, and route planners in China. The shapefile data for Shanghai's buildings include the information of building type, building groundbased area, height, and the number of floors for each building. These data are used in combination with land use data to further cluster the buildings into four different types including: residential, commercial, workplace, and industrial.

The land use data of 2013 from the Shanghai Planning and Land Bureau was depicted hierarchically into 3 sectors, 15 subcategories, and 73 subclasses of land use types using ArcGIS 10.6.1. The reclassification of the land use was conducted according to the National Standard of China "GB/T 2010-2017" (CSP, 2017) and covers residential area, commercial area, workplace area, and industrial area. Specially, the land use type of residential areas covers apartment, mixed apartment, housing in the rural, and empty housing. Commercial areas are the lands that are used for commercial operations. Workplace areas include land for medical care and health, charity, education, culture, government, research, market, and insurance. Industrial factories are classified into industrial areas.

The cost data of building construction used in this study are derived from the 2019 annual report provided by the consulting company Arcadis in Shanghai. The cost per square meter is based on Construction Floor Areas (CFA), which measures to the outside face of the external walls. The data set depicts four different building types (domestic, office/commercial, hotels, industrial, and other), which are further divided into 19 subsectors (Arcadis, 2020). Construction costs of various buildings are averaged in order to get the mean value for each building type (table 1).

Table 1. Common construction costs of various buildings in Shanghai.

\begin{tabular}{|c|c|c|c|}
\hline & Building Type & $\begin{array}{l}\text { Construction Cost } \\
\text { (USD } / \mathbf{m}^{2} \text { CFA) }\end{array}$ & $\begin{array}{c}\text { Average Construction Cost } \\
\left(\mathrm{USD} / \mathrm{m}^{2}\right)\end{array}$ \\
\hline \multirow{3}{*}{ Residential } & Apartments, high rise, high end & $1554-1697$ & \multirow{3}{*}{ 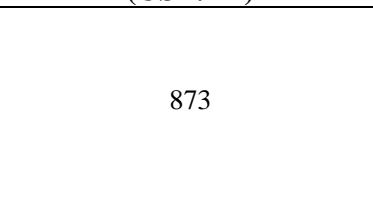 } \\
\hline & Terraced houses, average standard & $446-477$ & \\
\hline & Detached houses, high end & $666-740$ & \\
\hline Commercial & Retail malls, high end & $1228-1585$ & 1157 \\
\hline Office & High rise offices, prestige quality & $1158-1445$ & 1406 \\
\hline Industrial & $\begin{array}{l}\text { Industrial units, shell only (Conventional } \\
\text { single story framed units) }\end{array}$ & $432-540$ & 486 \\
\hline
\end{tabular}

The relationship between flood inundation depth and flood loss of a building or other property is depicted by a stage-damage function (Garrote et al., 2016; Mcgrath et al., 2019). Based on actual building damage data from past flood hazard events and previous empirical stage-damage functions in Shanghai (Yu et al., 2012; Wang, 2001), Ke (2014) developed updated stagedamage functions to specific buildings in Shanghai (Figure 2). These stage-damage functions represent the generalized loss of one type of buildings with similar properties, which are adopted in the present study. 


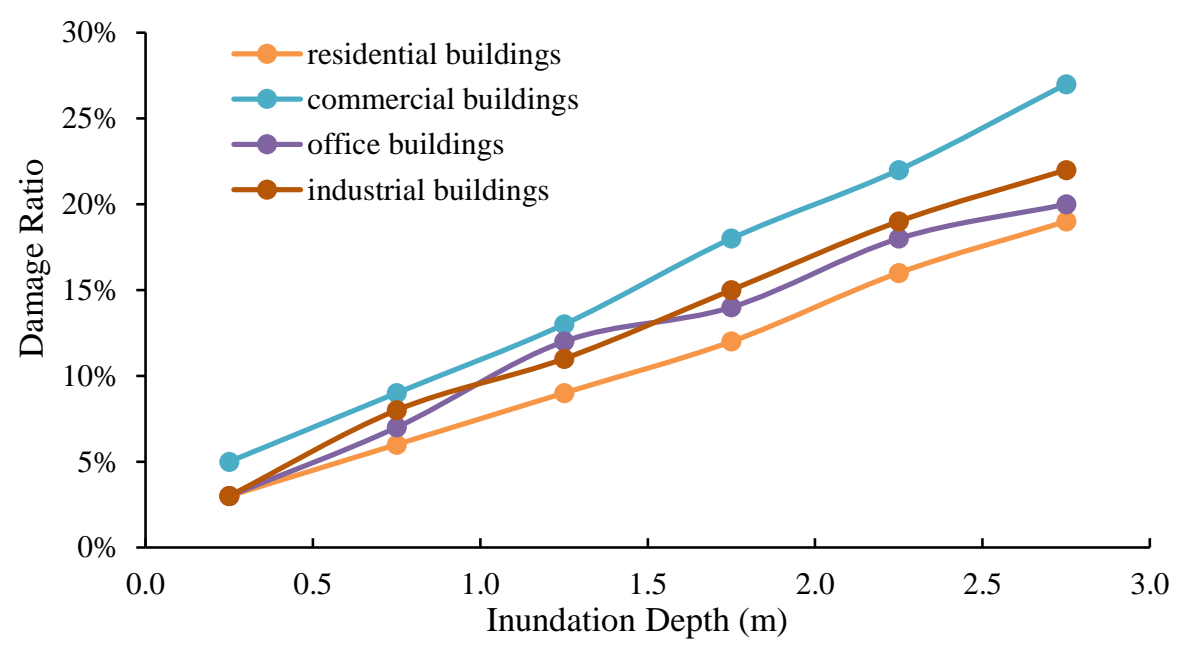

Figure 2. Stage-damage functions for buildings in Shanghai (Adopted from (Ke, 2014)).

\subsection{Methods}

In our study, the flood damages in Shanghai are estimated within three different steps: first, we calculated the asset values for each building based on the surface area of the building and the average construction cost. Then, the exposed building areas are determined by overlaying the distribution of buildings with the inundation maps for the four extreme flood scenarios. The damage values of a building could be estimated based on the exposed building area and the stage-damage functions. Finally, the overall flood risk for buildings in Shanghai, described as the estimated average annual loss (AAL), is calculated using a polynomial regression analysis. More details of the assessment are introduced in the following sections 2.3.1 to 2.3.4.

\subsubsection{Asset value analysis of buildings}

Different methods exist in the evaluation of building values. According to the Chinese National Standard (GB/T 50291-2015) and previous studies, there are four main approaches to evaluate the asset value of buildings: method of the sales comparison, method of the income capitalization, method of the construction cost, and method of the hypothetical development (CSP, 2015). The application of different methods depends on the specific study aims and the availability of building-specific data. Method of sale comparison is often used when the evaluation of a similar type of building is available. Method of income capitalization is suitable for buildings that yield profits like rents. If a building is newly constructed or (to be) reconstructed after damage, method of construction cost would be suitable for the evaluation. Method of hypothetical development is

150 applicable to the evaluation of real estate with investment development or redevelopment potentials. Since the present study aims to assess flood damages on buildings, the construction cost method is used with consideration of the building surface area. Then, the asset value of one building can be approximated by the following function:

$$
W_{n}=S_{n} \times P_{n}
$$


Where $W_{n}$ (USD) is the asset value of buildings for building type $n, S$ is the surface area of building $n, P_{n}$ is the construction cost $\left(\mathrm{USD} / \mathrm{m}^{2}\right)$ for the specific type of building $n$.

\subsubsection{Evaluation of building damages in flood}

The water depth of the flooding scenario determines the exposed area of the buildings. If the building is flooded at depth of more than 3 meters, we assume that the exposed area covers two floors instead of one. The potential building damages are determined by the stage-damage functions. The stage-damage function is used to evaluate the damage values of residential, commercial, workplace, and industrial buildings with the probability of 1/200, 1/500, 1/1000, and 1/5000-years extreme flood scenarios, respectively. The specific stage-damage functions are derived from existing studies on the relationship of various building loss rates with water-level depth in Shanghai (Penning-Rowsell et al., 2013; Ke, 2014). The damage values of one building can be expressed by the following function:

$$
f(x)=E_{n} \times P_{n} \times T_{n}
$$

165 Where $f(x)$ represents building damage for building type $n, E_{n}$ represents the exposed area of buildings for building type $n, P_{n}$ is the construction cost $\left(\mathrm{USD} / \mathrm{m}^{2}\right)$ for the specific type of building $n, T_{n}$ represents the damage proportion from stage-damage function for building $n$ under different water-level depths.

\subsubsection{Integrative building damages}

When expressing a city-scale flood damage for different flood scenarios, we use the already well established economic AAL (Hallegatte et al., 2013). The AAL is the sum of the probabilities of the floods for each return period, while considering the approximate areas under the associated risk curve (Ward et al., 2011). In the present study, we considered only the damage value of buildings as a major part of the AAL. Particularly, the AAL represents the integrative building damage for all types of buildings in all the considered flood scenarios in Shanghai. Hence, we get the AAL values for different exceedance probabilities (extreme flood scenarios) as the sum of:

$$
\mathrm{AAL}=\sum_{x=r p_{\min }}^{r p_{\max }-1}(f(x)+f(x+1)) / 2 \times \Delta x
$$

Where $\mathrm{n}$ is the building type, $x$ is the return period of the flood scenario, $f(x)$ is the damages value of one building.

\subsubsection{Spatial pattern identification}

In this study, the AAL of all sub-districts and their neighbours were compared with the AAL by Getis-Ord Gi* in ArcMap 10.6. The results contain a significant range of high values (hot spots) and low values (cold spots). Hot spots mean the AAL

180 of a sub-district has a high value and can be surrounded by other sub-districts with high values as well. Cold spots indicate an opposite situation. 


\section{Assessment of building damages in extreme floods}

\subsection{Mapping the flood scenarios}

This section presents the comparison of the spatial distribution of inundation areas under the four extreme flood scenarios

185 (Figure 3). The inundation areas increase generally, but non-linearly, along with increasing return periods. As shown in figure 3, the inundation areas mainly concentrate on regions around the Wusongkou (the mouth of Huangpu River), the Suzhou creek mouth (the central of Shanghai), the Songjiang-Qingpu low-lying area, and the north bank of Hangzhou Bay. The inundation areas expand to inland areas from the coastal region and the rivers as the flood scenario becomes more extreme. For the 1/200year flood scenario, $9 \%\left(488 \mathrm{~km}^{2}\right)$ of Shanghai is flooded, mainly along the north bank of Hangzhou Bay. The flooded area of Shanghai increased to $16 \%\left(868 \mathrm{~km}^{2}\right)$ and $24 \%\left(1302 \mathrm{~km}^{2}\right)$ in the $1 / 500$-year and 1/1000-year flood scenarios, respectively. The flooded area extended significantly to $49 \%\left(2659 \mathrm{~km}^{2}\right)$ of Shanghai in the 5000-year flood scenario. More specifically in this exceptionally extreme scenario, $32 \%$ of the city would be flooded with a water depth of $0-0.5 \mathrm{~m}, 11 \%$ with a $0.5-1.0 \mathrm{~m}$ depth of water, and $5 \%$ with a water depth of more than $1 \mathrm{~m}$ (Figure 3).

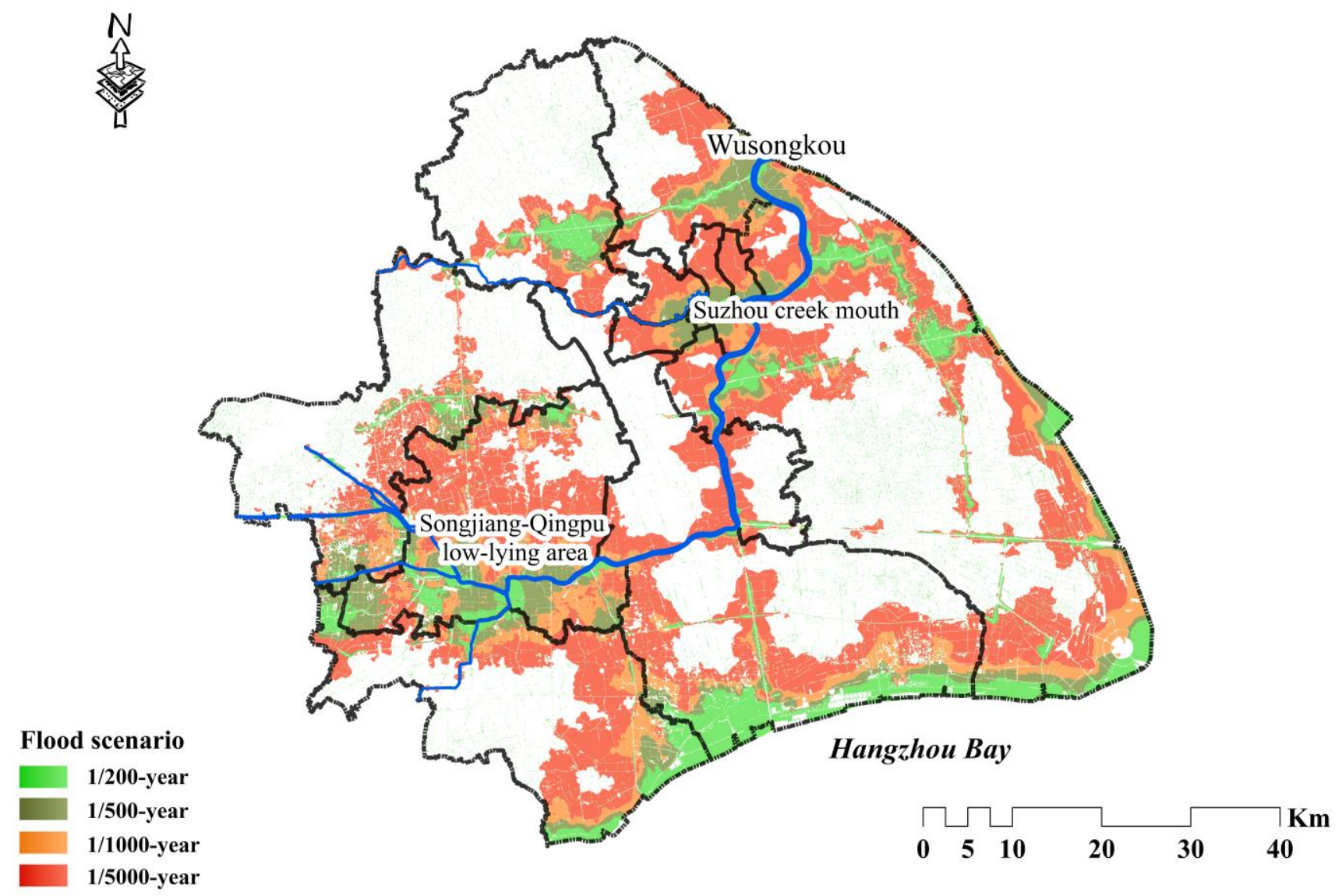

195 Figure 3. Inundation areas for the four flood return periods in Shanghai (excluding the area of islands). 


\subsection{Estimating the building assets}

This study identified the building floor area (BFA) of each type of building in 2017, which amounts to $816 \mathrm{~km}^{2}, 52 \mathrm{~km}^{2}, 152$ $\mathrm{km}^{2}$, and $300 \mathrm{~km}^{2}$ respectively for the residential, commercial, workplace, and industrial buildings. Accordingly, the building asset values are 2494, 212, 747, and 510 billion USD considering the Average Construction Cost (see Table 1) of each building types in 2019. This is a conservative estimation as the actual present value of the buildings are certainly higher due to new developments in recent years. The relative numbers show that residential buildings have the highest asset value, followed by office, industrial, and commercial building.

Figure 4 shows that all types of buildings have higher values within the outer ring of Shanghai. This is consistent with the fact that the central downtown area is densely developed with the accumulation of various buildings. While comparing the building asset values in the 15 districts, the Pudong district has the highest asset value and largest building surface area (Table 2) as it is the largest district in Shanghai.

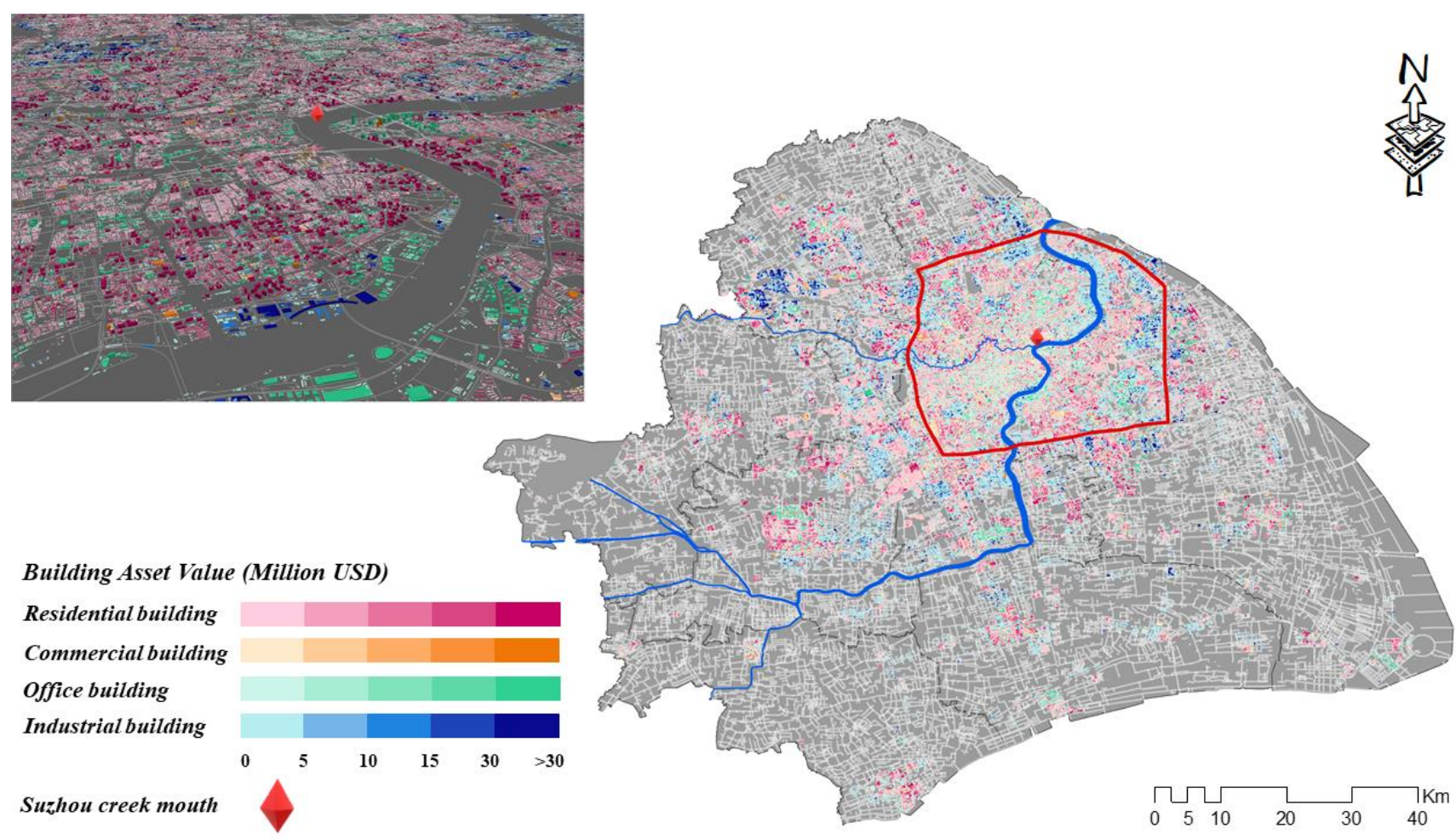

Figure 4. The distribution of building asset values in different types of buildings in Shanghai.

Table 2. The building asset values and floor areas in the 15 districts of Shanghai.

\begin{tabular}{|c|c|c|c|c|c|c|c|c|}
\hline \multirow{2}{*}{ District } & \multicolumn{2}{|c|}{ Residential } & \multicolumn{2}{|c|}{ Commercial } & \multicolumn{2}{|c|}{ Office } & \multicolumn{2}{|c|}{ Industrial } \\
\hline & $\begin{array}{c}\text { Asset Value } \\
\text { (Billion USD) }\end{array}$ & $\begin{array}{c}\text { Surface Area } \\
\left(\mathbf{k m}^{2}\right)\end{array}$ & $\begin{array}{c}\text { Asset Value } \\
\text { (Billion USD) }\end{array}$ & $\begin{array}{c}\text { Surface Area } \\
\left(\mathbf{k m}^{2}\right)\end{array}$ & $\begin{array}{c}\text { Asset Value } \\
\text { (Billion USD) }\end{array}$ & $\begin{array}{c}\text { Surface Area } \\
\left(\mathbf{k m}^{2}\right)\end{array}$ & $\begin{array}{c}\text { Asset Value } \\
\text { (Billion USD) }\end{array}$ & $\begin{array}{c}\text { Surface Area } \\
\left(\mathbf{k m}^{2}\right)\end{array}$ \\
\hline Jiading & 236 & 271 & 25 & 22 & 54 & 39 & 89 & 183 \\
\hline Fenxian & 64 & 73 & 9 & 8 & 17 & 12 & 8 & 16 \\
\hline
\end{tabular}




\begin{tabular}{ccccccccc}
\hline Baoshan & 260 & 298 & 22 & 19 & 48 & 34 & 64 & 131 \\
Xuhui & 117 & 133 & 10 & 9 & 58 & 41 & 16 & 33 \\
Putuo & 133 & 152 & 13 & 11 & 28 & 20 & 18 & 37 \\
Yangpu & 90 & 104 & 6 & 5 & 58 & 41 & 22 & 45 \\
Songjiang & 217 & 249 & 12 & 10 & 40 & 29 & 27 & 55 \\
Pudong & 616 & 705 & 51 & 44 & 200 & 142 & 164 & 336 \\
Hongkou & 72 & 82 & 3 & 3 & 22 & 16 & 4 & 7 \\
Jingshan & 42 & 48 & 6 & 5 & 8 & 6 & 2 & 4 \\
Changning & 59 & 68 & 1 & 1 & 25 & 18 & 4 & 9 \\
Minhang & 303 & 347 & 35 & 30 & 69 & 49 & 58 & 119 \\
Qinpu & 128 & 146 & 6 & 5 & 59 & 42 & 15 & 31 \\
Jingan & 96 & 110 & 7 & 6 & 32 & 23 & 18 & 37 \\
Huangpu & 61 & 70 & 5 & 4 & 28 & 20 & 3 & 5 \\
Total & 2494 & 2857 & 212 & 183 & 747 & 531 & 510 & 1050 \\
\hline
\end{tabular}

\subsection{Exposed building values}

The quantitative assessment and mapping generated the spatial extent of exposed buildings and the exposed building values under the four extreme flood scenarios in Shanghai (Figure 5). The assessment shows that the total exposed building values reach 39, 107, 166, and 386 billion USD under a 1/200, 1/500, 1/1000, and 1/5000-year flood scenarios, respectively. Exposed buildings in the 1/200 scenario are located mainly along the coast and rivers, with some exposed buildings in dispersed lowlying places. With an increase of extreme flooding, the exposed areas rise rapidly and become contiguous. Under the most extreme scenario of a 1/5000-year return period, the region around the Suzhou Creek Mouth in the inner city is remarkably exposed in deep water with the highest exposed values. Two contiguous inundation areas, central Shanghai and the SongjiangQingpu low-lying area in west Shanghai, are identified as the most seriously exposed regions in the most extreme flood scenario (Figure 5d).

Unsurprisingly, as the residential buildings have the highest asset value, their exposed values are also the highest in the four types of buildings (Appendices Table A1). Further analysis of the exposed values in different districts indicates that Pudong has the highest exposed value for all four flood scenarios (Table 3). The exposed ratio of each district in different flood scenarios is as follows: in the 1/200-year flood scenario, Fengxian has the highest percentage of exposed building values; under the 1/500-year and 1/1000-year flood scenarios, Huangpu has the highest percentage of exposed building values. Under the 1/5000 flood scenario, Hongkou has the highest percentage (Appendices Figure A1).

Water depth is a determinate factor of exposed building values. Though hardly visible in Figure 5, 94\% of the exposed buildings are exposed to water levels of $0-0.5 \mathrm{~m}$ in the $1 / 200$-year flood scenario (Figure $5 \mathrm{a}$ ). The account declines to $82 \%$, $83 \%$ and $67 \%$ under the $1 / 500,1 / 1000$, and 1/5000-year flood scenarios, due to the increasing proportions of exposures in deeper water. In the case of the most extreme 1/5000-year flood scenario, $24 \%$ of exposed buildings are in water of $0.5-1 \mathrm{~m}$, and $8 \%$ of the exposed buildings are flooded in depth of 1-1.5m (Appendices Figure A2). 
(a) $1 / 200$

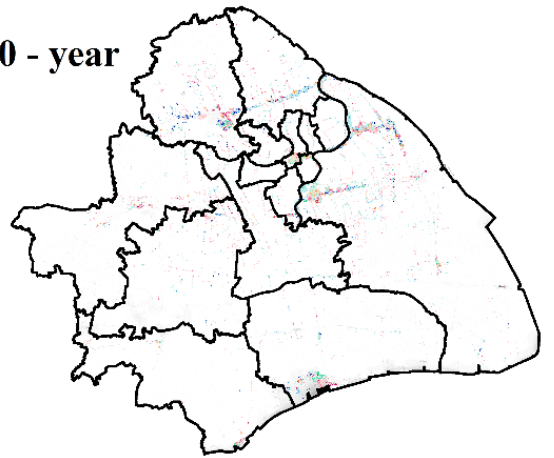

(c) 1/1000 - year

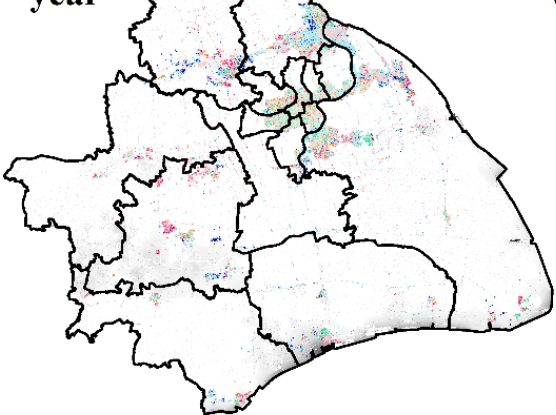

Building exposed value (Million USD)

Residential building

Commercial building

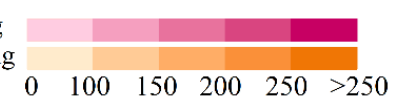

(b)

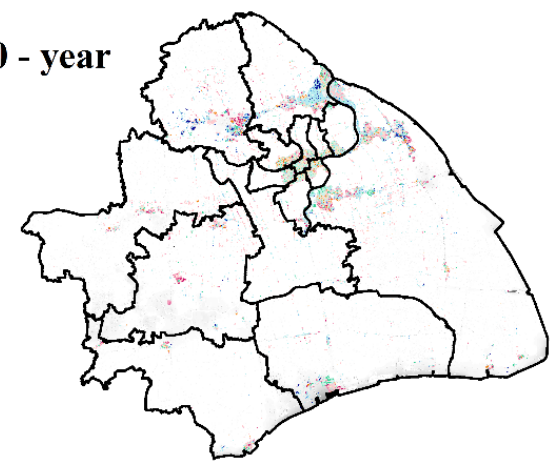

(d)

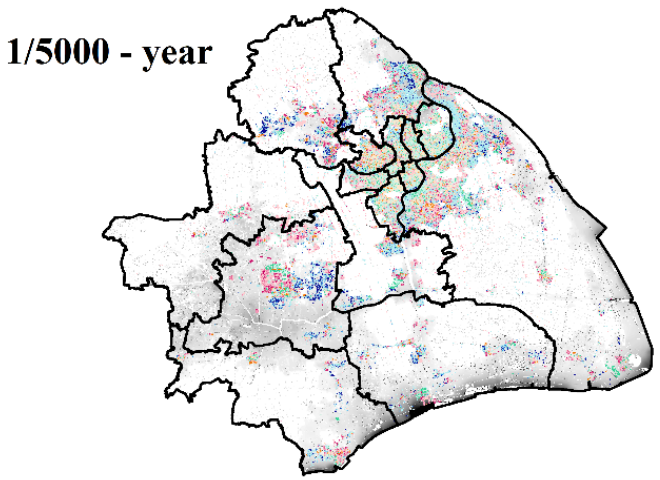

Flood depth (m)

Office building

Industrial building

$\begin{array}{llllll}0 & 100 & 150 & 200 & 250 & >250\end{array}$

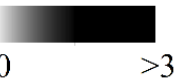

Figure 5. The distribution of exposed asset values for residential, commercial, office, and industrial buildings under four extreme flood scenarios in Shanghai.

Table 3. Exposed building values of the 15 districts in Shanghai under the four flood scenarios (Unit: Billion USD).

\begin{tabular}{ccccc}
\hline Districts & \multicolumn{4}{c}{ Flood scenarios (Return Periods) } \\
& $\mathbf{1 / 5 0 0 0}$ & $\mathbf{1 / 1 0 0 0}$ & $\mathbf{1 / 5 0 0}$ & $\mathbf{1 / 2 0 0}$ \\
\hline Jiading (JD) & 23.27 & 11.48 & 9.00 & 5.96 \\
Fengxian (FX) & 9.69 & 4.03 & 2.93 & 2.69 \\
Baoshan (BS) & 43.52 & 25.87 & 17.39 & 2.61 \\
Xuhui (XH) & 23.43 & 7.19 & 4.79 & 0.70 \\
Putuo (PT) & 23.22 & 11.32 & 6.76 & 0.27 \\
Yangpu (YP) & 24.75 & 8.51 & 3.89 & 0.36 \\
Songjiang (SJ) & 35.67 & 9.54 & 3.48 & 0.96 \\
Pudong (PD) & 111.16 & 46.79 & 31.95 & 17.41 \\
Hongkou (HK) & 15.53 & 5.04 & 3.02 & 0.05 \\
Jinshan (JS) & 8.19 & 3.69 & 2.29 & 1.20 \\
Changning (CN) & 13.66 & 8.28 & 4.97 & 0.12 \\
Minhang (MH) & 15.56 & 0.93 & 0.55 & 0.62 \\
\hline
\end{tabular}


https://doi.org/10.5194/nhess-2021-382

Preprint. Discussion started: 23 December 2021

(C) Author(s) 2021. CC BY 4.0 License.

(c) (i)
Natural Hazards

and Earth System

Sciences

Discussions

\begin{tabular}{ccccc}
\hline Qingpu (QP) & 5.24 & 2.62 & 1.93 & 1.06 \\
Jingan (JA) & 19.41 & 9.47 & 8.13 & 3.02 \\
Huangpu (HP) & 13.69 & 11.56 & 5.73 & 1.96 \\
Total & 385.98 & 166.31 & 106.80 & 38.99 \\
\hline
\end{tabular}

\subsection{Damages of buildings in floods}

The quantitative assessment provides maps of flood damages to different buildings under the four extreme scenarios (Figure 6). The total building damages in the 1/5000-year flood scenario is 18 billion USD, which is more than 10 times the $1 / 200$ year flood scenario (1.39 billion USD). Again, residential buildings are the most damaged in all four scenarios with a damage value of up to 9.6 billion USD in the 1/5000-year scenario. Damages of industrial buildings, office buildings and commercial buildings would reach 1.6, 4.0, and 3.0 billion USD respectively under the 1/5000-year flood scenarios.

The damage analysis of different districts shows that Pudong has the highest overall damage in all scenarios (Table 4). However, the rankings of the proportion of damages are different. For the 1/200-year scenario, Fengxian has the highest proportion of the asset damages. Jingan has the highest damage proportion in the 1/500-year scenario. While for the 1/1000 and 1/5000-year scenarios, Huangpu is ranking as the most damaged district in terms of the damage proportion (Appendices

245 Figure A3).

In terms of damage due to water depths in different flood scenarios, water depths of $0-0.5 \mathrm{~m}$ causes 83 percent of building damage in the 1/200-year flood scenario. Under 1/500, 1/1000, and 1/5000-year flood scenarios, the proportion are $67 \%$, $68 \%$, and $44 \%$, respectively, with deeper water depths causing more damage. For instance, 35\% of buildings are damaged in water depths of $0.5-1 \mathrm{~m}$ under the 1/5000-year flood scenario, and 17\% of the damages occur in water depths 1 -1.5m (Appendices

250 Figure A4). 
(a)

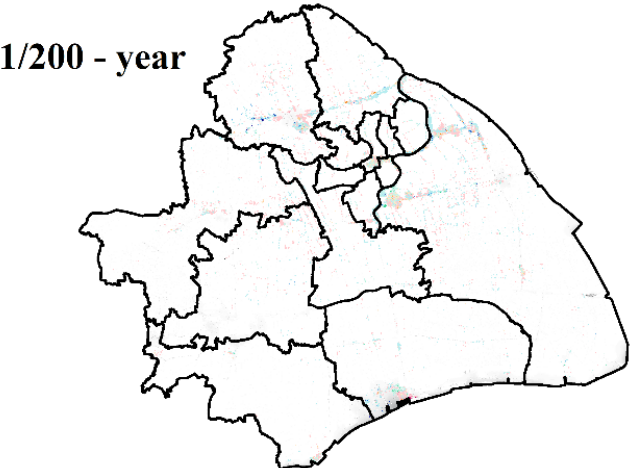

(b) $1 / 500$ - year

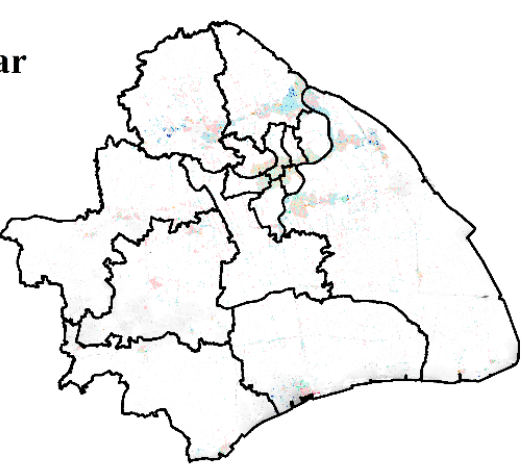

(c) 1/1000 - year

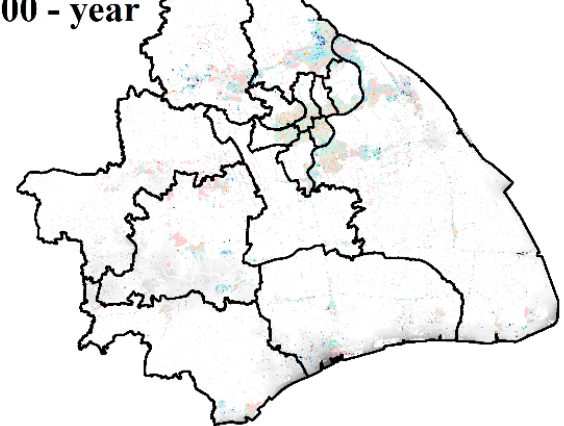

(d) $1 / 5000$ - year

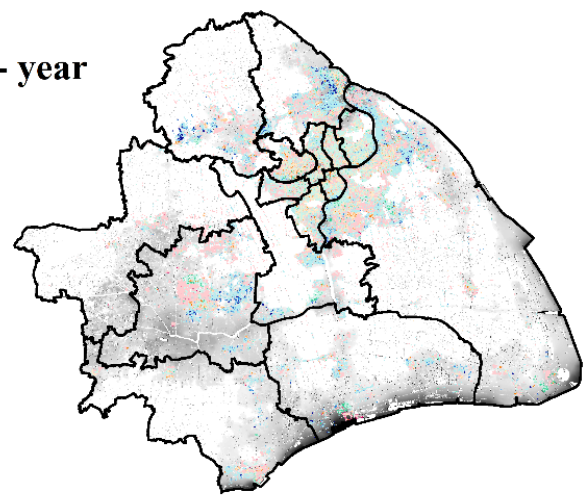

Building losses value (Thousand USD)

Residential building Commercial building

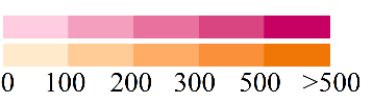

\section{Office building} Industrial building
Flood depth (m)

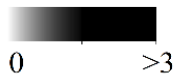

Figure 6. The distribution of damaged asset values for residential, commercial, office, and industrial buildings under the four extreme flood scenarios in Shanghai.

Table 4. Statistics of damage to residential, commercial, office and industrial buildings to extreme flooding under four return

period scenarios in districts (Unit: Billion USD).

\begin{tabular}{|c|c|c|c|c|}
\hline \multirow{2}{*}{ Asset Damages District } & \multicolumn{4}{|c|}{ Return Periods } \\
\hline & $1 / 5000$ & $1 / 1000$ & $1 / 500$ & $1 / 200$ \\
\hline Jiading (JD) & 0.81 & 0.42 & 0.30 & 0.20 \\
\hline Fengxian (FX) & 0.55 & 0.28 & 0.20 & 0.17 \\
\hline Baoshan (BS) & 2.42 & 1.04 & 0.58 & 0.09 \\
\hline Xuhui (XH) & 1.07 & 0.31 & 0.17 & 0.02 \\
\hline PuTuo (PT) & 1.24 & 0.53 & 0.26 & 0.01 \\
\hline Yangpu (YP) & 1.15 & 0.34 & 0.14 & 0.01 \\
\hline Songjiang (SJ) & 1.31 & 0.33 & 0.11 & 0.03 \\
\hline Pudong (PD) & 4.74 & 1.71 & 1.10 & 0.59 \\
\hline Hongkou (HK) & 0.78 & 0.24 & 0.12 & 0.00 \\
\hline Jinshan (JS) & 0.37 & 0.16 & 0.09 & 0.05 \\
\hline Changning $(\mathrm{CN})$ & 0.82 & 0.42 & 0.22 & 0.01 \\
\hline
\end{tabular}




\begin{tabular}{ccccc}
\hline Minhang (MH) & 0.54 & 0.05 & 0.02 & 0.02 \\
Qingpu (QP) & 0.20 & 0.10 & 0.06 & 0.03 \\
Jinan (JA) & 1.23 & 0.62 & 0.46 & 0.09 \\
Huangpu (HP) & 0.95 & 0.53 & 0.26 & 0.06 \\
Total & 18.18 & 7.08 & 4.10 & 1.39 \\
\hline
\end{tabular}

\subsection{Integrative evaluation of flood damages in Shanghai}

By integrating the extreme flood scenarios and associated building damages for the four types of buildings, we plotted the four average annual probability-damage curves (Fig. 7). The AALs of residential, commercial, workplace, and industrial buildings are 18.3, 3.6, 7.8, and 5.8 million dollars, respectively. It is clear that residential buildings would suffer the highest damage value among the four types of buildings.

By using the Getis-Ord Gi* statistic tool (Hot Spot Analysis) in ArcMap 10.6, the results reveal the distuibution of high and low building damages for different types of buildings in the community level in Shanghai (Fig. 8). Apparently, the distribution of hot spots and cold spots for different types of buildings are quite different. For residential buildings, there are six hot spot areas and five cold spot areas. Most of the hot spot areas concentrate in the ciy center except for one along the north coast of Hangzhou Bay. Further analysis of the commercial buildings indicates a significant hot spot south of the Suzhou Creek Mouth. Figure 7c shows five hot spot areas and two cold spot areas for office buildings with three hot spots located in coastal areas. Four hot spots of industrial buildings concentrate mainly in the north, while the city center is the main cold spot area because few industrial buildings are located there.

270 Overall, the city center is the hot spot area of flood damages for the residential, commercial and office buildings (Figure 8a, $8 \mathrm{~b}$ and $8 \mathrm{c}$ ). But in contrast, the city center is the cold spot area for the industrial buildings (Figure 8d). Wusongkou is a hotspot for four different types of structures. Wusongkou floods in all four flood scenarios, and the inundation area expands as the retrun-period expands. Another reason is that the density of building in Wusongkou is higher than in other areas.

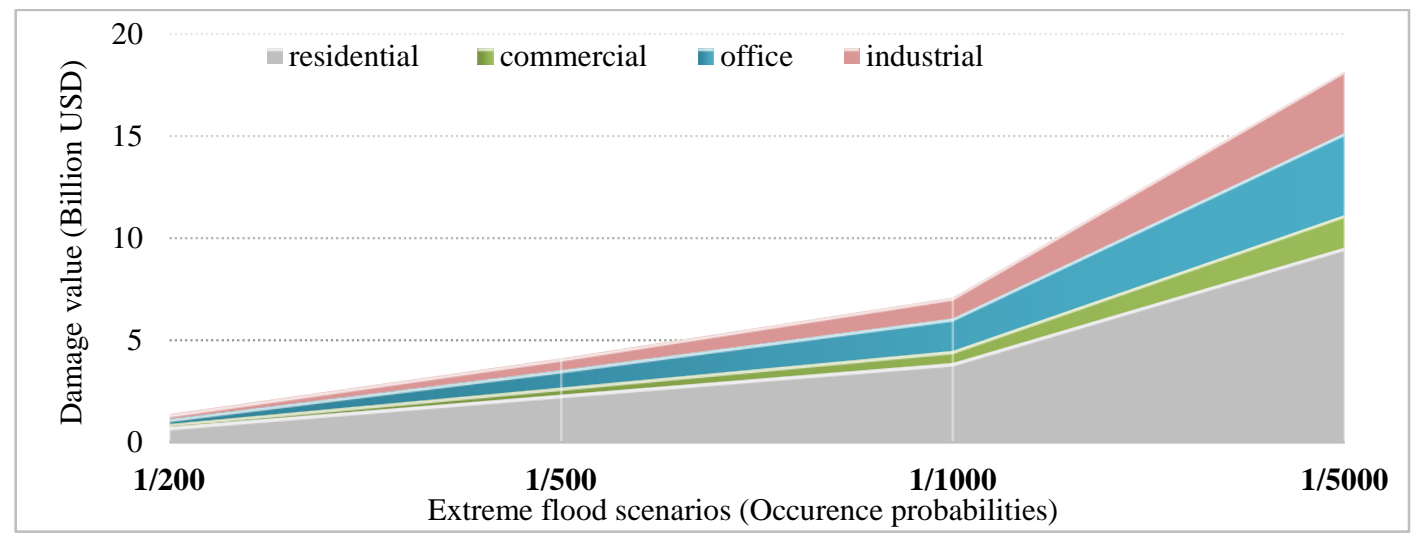

275 Figure 7. Stage-damage curve of extreme flooding for residential building, commercial building, office building, industrial building and the sum of residential, commercial, office and industrial buildings in Shanghai. 

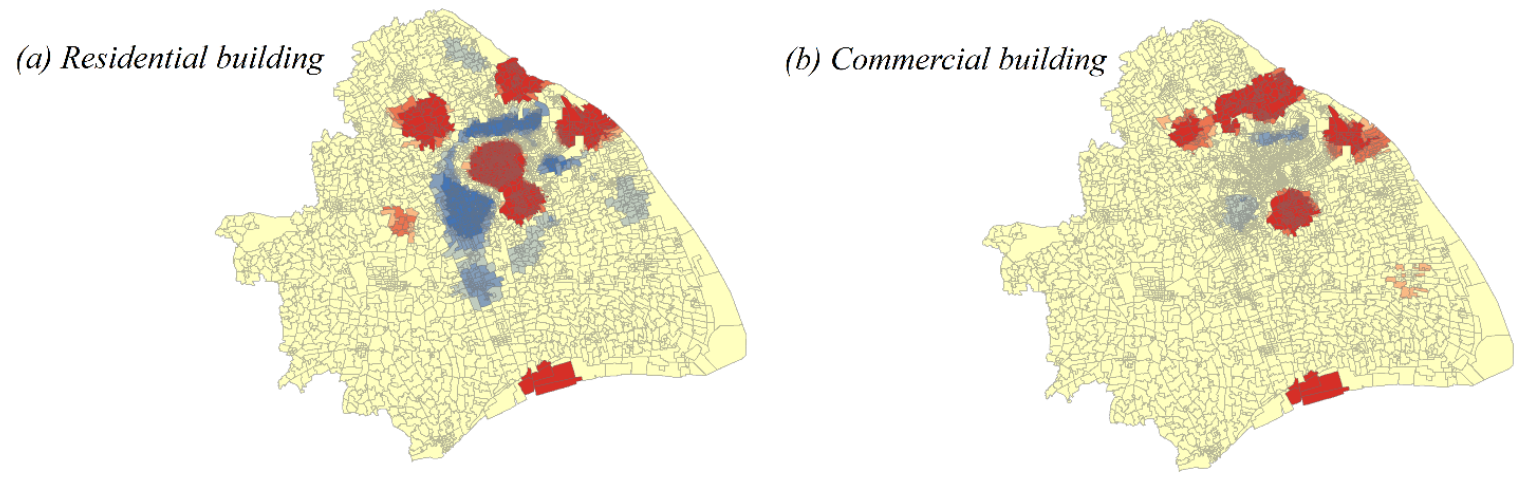

(c) Office building

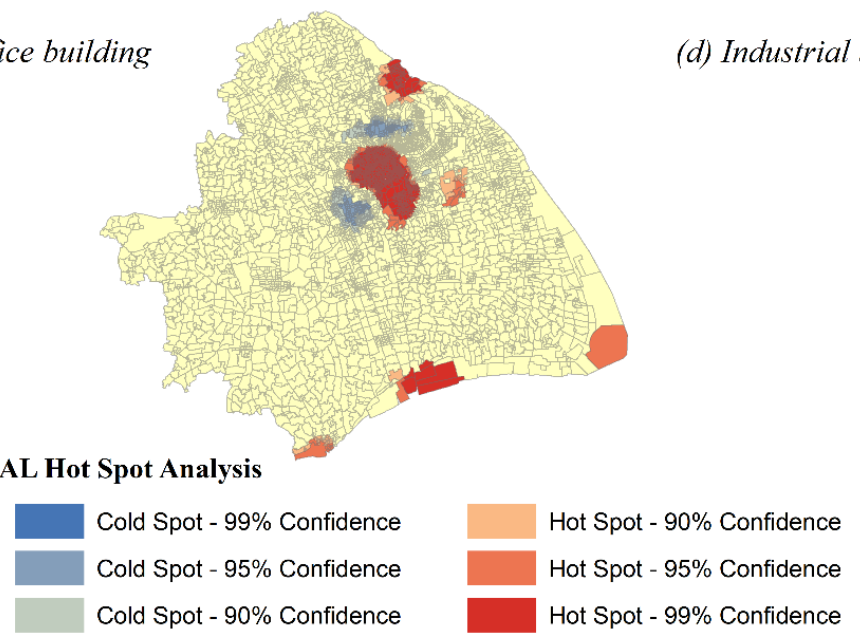

Figure 8. The hot spot analysis of the AAL for buildings at sub-district level in Shanghai.

\section{Discussion}

AAL Hot Spot Analysis
Hot Spot - 95\% Confidence

Hot Spot - 99\% Confidence

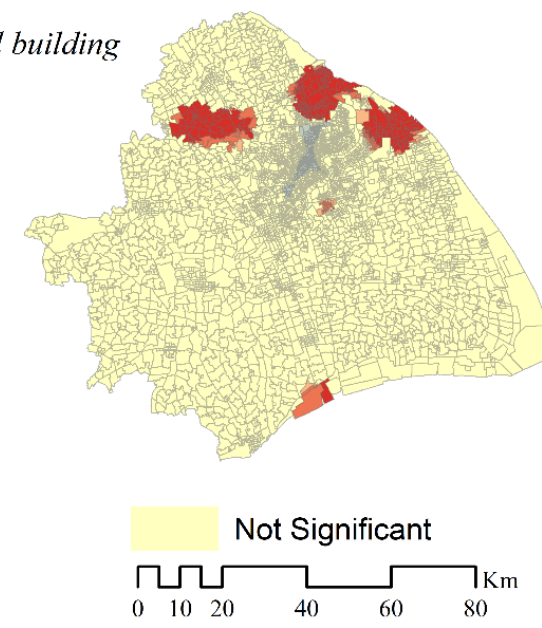

\subsection{Evaluation of the flood risk in Shanghai and implications for the future}

Our study shows that the damage to buildings in Shanghai grows exponentially with the decreasing likelihood of extreme flood scenarios. For instance, the resulting flood damages to residential, commercial, workplace, and industrial buildings under the 1/5000-year flooding scenario is more than ten times the resulting damages from a 1/200-year flooding scenario. As shown in section 3.1, the area along the Yangtze River Estuary, Hangzhou Bay and Huangpu River are broadly flooded under the 1/200, $2851 / 500,1 / 1000$, and 1/5000-year flooding scenarios. The results of the study show the importance of assessing the risk to extreme events on regional scale at a high spatial resolution considering the differences in the exposed assets. The hot-spot clusters are distributed over the whole study area and vary from building type to building type. In some areas, the damage is driven mainly by high inundation depths (e.g., the hotspot in the south), whereas other areas face a high risk due to the high 
vulnerability of the asset values. This shows the importance of assessing the different drivers of risk on local scale for the selection and dimensioning of adequate protection measures against extreme events.

Concerning increases in climate change, the frequency and/or severity of acute climate hazards and the intensification of chronic hazards will increase the flood risks in Shanghai in the future (Woetzel et al., 2020b). The Sixth Intergovernmental Panel on Climate Change (IPCC) found that global precipitation will intensify and become more frequent in most regions with additional global warming (IPCC, 2021). Extreme precipitation events increased dramatically by $10 \%$ to $20 \%$ every 10 years during the 1951 - 2001 period in the Yangtze River basin, China (Wang and Zhou, 2005). Concerning Shanghai, after analysing Shanghai's hourly precipitation records (1916 - 2014), Liang and Ding (2017) found a rate increase of 1.5 and 1.8 for heavy precipitation events. Precipitation events now increase the possibility of seawall and levee failures in Shanghai. One 1/1000year return period flood occurred in Shanghai in 2013, breaking the highest crest record at Wusongkou Datum and causing levees to breakdown (Ke et al., 2018). As a result of climate change, extreme flooding events will become more common in Shanghai.

Human activities can also increase the likelihood of flood risk in Shanghai. For instance, changes in land subsidence relative to the sea level rise could increase the flood risk to Shanghai. Due to the extraction of ground water, construction of high-rise buildings and underground projects (Gong et al., 2008), the average annual rate of land subsidence was $7 \mathrm{~mm}$ between 2007 and 2010 (Wu et al., 2012), and then the rate decreased to $5 \mathrm{~mm} /$ year after 2010 (Yin, 2011). However, the maximum annual subsidence rate in Shanghai could still have a chance to reach $24.12 \mathrm{~mm} / \mathrm{year}$ (Wang et al., 2012). On the other hand, sea levels will rise a maximum of $86.6 \mathrm{~mm}, 143 \mathrm{~mm}, 185.6 \mathrm{~mm}$, and $433.1 \mathrm{~mm}$ by 2030, 2040, 2050, and 2100, respectively in Shanghai (Wang et al., 2012; Wu et al., 2012). Future flood damage in Shanghai will be exacerbated by increased precipitation, land subsidence and sea level rise, which further shows the need to adapt to the (currently) low probability-high impact events.

\subsection{Adaptation strategies to extreme floods in Shanghai}

310 Effective adaptation to increasing flood risks requires an integrated climate response strategy, which shall include a broad scope of intervention measures such as urban planning, structural flood management measures, early warning systems, naturebased solutions, flood awareness and risk financing instruments (Yang et al., 2015; Jongman, 2018). Urbanization as a confirmed trend in the fast-developing coastal city may increase asset exposures to floods, but can also offer opportunities for improving flood risk management (Garschagen and Romero-Lankao, 2015). A top-down urban master plan, including land

315 use planning, control of runoff, access to data and information, etc. should be updated, by the Shanghai Municipal Government, to involve advanced risk management measures (Zhou et al., 2017). For instance, in its Master Plan 2017 - 2035, Shanghai is going to further develop its five new district centers at Jiading, Songjiang, Qinpu, Fengxian and Nanhui. These five district centers are planned to be nodal areas in Shanghai and provide more public services for the growing population. However, based on the flood scenario maps, the Songjiang-Qingpu low-lying area is a hot spot of flood damages. Therefore, future flood

320 protections in these locations, particularly the drainage system and the building structures, must be designed to a higher standard. 
The hard, soft and hybrid measures must be considered in implementing the planned urbanization process (Table 5). It has been widely proven that the hard strategies can effectively reduce the flood hazard probability. For instance, the direct economic flood loss significantly decreased after a series of integrated flood management followed a mega-flood across central and south China in 1998 (Bryan et al., 2018). The protection level of existing seawalls and levees along the Changjiang Estuary, Hangzhou Bay and Huangpu River do not provide adequate protection to meet Shanghai's current flood defense standards. These structures are not sufficient to protect the increasing urban assets considering the combined impacts of climate change, land subsidence and typhoon events.

Table 5. Comparison of flood adaptation measures in Shanghai

\begin{tabular}{|c|c|c|c|}
\hline Categories of measures & Specific measures & Effects & Suitability \\
\hline \multirow{4}{*}{ Hard measures } & Seawall and levees & $\begin{array}{l}\text { Protects areas from being flooded or eroded } \\
\text { by extreme storms, floods, astronomical } \\
\text { tides, and sea level rise, particularly in low } \\
\text { lying areas. }\end{array}$ & $\begin{array}{l}\text { Raise levees and construct a flood barrier in } \\
\text { Wusongkou which could lower the flood } \\
\text { pressure from Huangpu River (Wang et al., } \\
\text { 2011). }\end{array}$ \\
\hline & Drainage system & \begin{tabular}{|l|} 
Rapid rainfall discharge to improve \\
transport and safeguard property.
\end{tabular} & $\begin{array}{l}\text { The drainage system should protect Shanghai } \\
\text { under 50-year flood scenario. The capacity } \\
\text { should be enhanced to the probability period of } \\
100 \text { years in the vulnerability (UPLR, 2018). }\end{array}$ \\
\hline & Reservoir & $\begin{array}{l}\text { Save part of the precipitation and reduce } \\
\text { flood pressure in downstream or lowland } \\
\text { areas. }\end{array}$ & $\begin{array}{l}\text { Adjust stock by season or weather forecasting, } \\
\text { relieve the pressures of the city flood } \\
\text { management during floods. }\end{array}$ \\
\hline & Channel & $\begin{array}{l}\text { Relieve the flood pressure and speed up } \\
\text { drainage within the city. }\end{array}$ & $\begin{array}{l}\text { Ensure that the dam functions could be running } \\
\text { on the Huangpu River and Suzhou River. }\end{array}$ \\
\hline \multirow{7}{*}{ Soft measures } & Warning system & $\begin{array}{l}\text { Enable stakeholders or households to } \\
\text { prepare for the extreme climate and react } \\
\text { to mitigate it. }\end{array}$ & $\begin{array}{l}\text { Could be used in Shanghai, especially } \\
\text { preventing people from putting their lives in } \\
\text { extreme flood event. }\end{array}$ \\
\hline & Dry proofing & $\begin{array}{l}\text { Being watertight with all elements } \\
\text { substantially impermeable to the entrance } \\
\text { of flood and with structural components } \\
\text { having the capacity to resist flood loads } \\
\text { (FEMA, 2013). }\end{array}$ & $\begin{array}{l}\text { Help the household, especially for household } \\
\text { that have experienced regular flooding, to stop } \\
\text { the floodwater from their entrance door. }\end{array}$ \\
\hline & Wet proofing & $\begin{array}{l}\text { Allow water to enter the building but } \\
\text { minimizing damage. }\end{array}$ & $\begin{array}{l}\text { Minimizing the damage of property in the } \\
\text { building in the flood-prone area. }\end{array}$ \\
\hline & $\begin{array}{l}\text { Detention and } \\
\text { retention areas }\end{array}$ & $\begin{array}{l}\text { Alleviate flood peak by artificially made } \\
\text { storage areas (Glavan et al., 2020) }\end{array}$ & $\begin{array}{l}\text { Based on Sponge City project, to capture, purify } \\
\text { and store more water (Griffiths et al., 2020). }\end{array}$ \\
\hline & Emergency relief & $\begin{array}{l}\begin{array}{l}\text { Personnel evacuation and transfer of } \\
\text { property from short-term extreme } \\
\text { precipitation. }\end{array} \\
\end{array}$ & $\begin{array}{l}\text { Adapted in Shanghai, especially residents who } \\
\text { lived in inundation areas in the extreme flood } \\
\text { scenario. }\end{array}$ \\
\hline & Insurance & $\begin{array}{l}\text { Increase financial resilience to floods } \\
\text { (Surminski and Oramas-Dorta, 2014). }\end{array}$ & $\begin{array}{l}\text { Meet the needs of vulnerable individuals, } \\
\text { households and micro, small, and medium- } \\
\text { sized enterprises (MSMEs) in Shanghai (Hess } \\
\text { and Fischle, 2019). }\end{array}$ \\
\hline & Wetlands & $\begin{array}{l}\text { Provide valuable flood storage, buffer } \\
\text { storm surge, and assist in erosion control } \\
\text { (EPA, 2021). Absorb and slow down the } \\
\text { floodwater from storm surge. }\end{array}$ & $\begin{array}{l}\text { The wetland on the north of Hangzhou Bay, } \\
\text { the mouth of Yangtze River should be } \\
\text { protected to slow down the erosion from the } \\
\text { storm surge and sea level rise. }\end{array}$ \\
\hline
\end{tabular}


Particularly for the hot spot areas where huge damages are expected, extra coping strategies must be taken seriously into consideration. For instance, underground water storage and pumping facilities are necessary for the city center, and these shall be systematically planned together with detention and retention regions on the ground. A feasible and practical way is to make use of the old air defense facilities and some underground parking lots (Chen et al., 2018). Researchers have mentioned, and we also recommend, to enhance the bank and build a water wall in the estuary area of the Huangpu River (Chen et al., 2018), because of the large population and assets which deserves a high level of protection. Developing such a flood barrier and upgrading the Huangpu-River floodwalls to a protection standard of a 1/1000-year flood event in Shanghai could significantly reduce the expected annual flood damages to 0.07 - 0.5 billion/year in 2100 for the RCP (representative concentration pathway) 4.5 scenario (Du et al., 2020).

340 Potential flood risks coming from extremely low-probability storm surges can be further reduced by combining the soft strategy. For instance, dry proofing and wet proofing, as well as the coastal wetland strategies can be combined to form a hybrid strategy in specific regions. Although soft measures on their own cannot maintain the future flood risk at a low level, they can play a critical role in reducing potential damages. Additionally, the soft measures such as maintaining coastal wetlands can enhance social welfare by providing multiple ecosystem services. Challenges may rise in that homeowners are on average not inclined to install soft strategies due to the high costs for individual households, even if they live in flood plains (De Ruig et al., 2020). On the other hand, extreme flood scenarios often cause more serious flood damage to households because they occur very soon and leave less time for responding (Yang et al., 2018b). Thus, an efficient forecasting and early warning system is needed which could help individuals, businesses, communities and government leave dangerous zones, transfer house property and improve preparedness with sufficient lead time (UN, 2020). Insurance also plays a very important role in the support of various people and groups to recover from flood hazards, especially for the high-risk regions.

\subsection{Uncertainties and limitations of the assessment}

The integrative analysis of geospatial building asset maps, flood scenarios and the stage-damage functions in the study makes it possible to assess the flood damage of buildings in the mega city Shanghai with a high spatial resolution. However, the accuracy of building asset values could still be improved. First, the adopted building data of location, footprint area, height and floors didn't consider the construction materials used and years built. Also, the data from 2013 is not very new, considering the fast development of Shanghai. Second, the classification of different types of buildings is quite straightforward based on the land use/land cover data. However, many buildings with multiple functions (e.g., shopping mall and offices) were identified to a single building type, which causes uncertainties of the building value. Third, existing studies' stage-damage functions for specific types of buildings are used to create the asset building loss map for the flood risk assessment. The functions must be

360 updated and tailored to more current and specific building conditions, particularly when estimating flood damages in the future (Ke, 2014).

Our assessment of the building damages is comparatively less than those in similar studies of Shanghai. The major reason is that we adopted the construction cost as the values of different buildings, while many other studies calculated the market value 
of buildings and the associated properties. For instance, Wu et al. (2019) estimated the exposed building asset value in Shanghai to be roughly 304.1 billion USD with a total damage of approximately 32.2 billion USD for a 1/1000-year flood event. Shan et al. (2019) estimated the loss of the residential buildings to be 27.1 billion USD using house price data under a 1/1000-year flood event in Shanghai.

The four extreme flood scenarios in Shanghai were taken from published models in Shanghai that are induced by atmospheric, hydrology, and coastal models (Wang et al., 2019). However, the climatic impact-drives (CIDs) such as the frequency of sea level rise, heavy precipitation, and pluvial floods can be altered as a result of various greenhouse gas (GHG) emissions. For example, every $0.5^{\circ} \mathrm{C}$ rise in global warming increases the severity and frequency of heat extremes, such as heatwaves and heavy rains, as well as agricultural and ecological droughts in some regions (IPCC 2021). Therefore, the CIDs (e.g., sea level rise, heavy precipitation) should be considered in future flood simulation models and studies.

\section{Conclusion}

375 This study presents an integrated impact model of flood damage to buildings based on extreme flooding scenarios in Shanghai. The results show that the inundation area is significantly larger in the low probability of extreme flood scenarios. In all the four considered scenarios, the areas near the Huangpu River and along the shore are always the affected with building damages. The central downtown areas of Shanghai have a high risk of being exposed to and affected by extreme floods, partly because of its high building density. Besides that, the Songjiang-Qingpu low-lying area in the west of Shanghai has been recognized as a noticeable area to be flooded under a 1/5000-year flood scenario. This calls for special concerns in the near future because the Songjiang-Qingpu area is planned to become an important sub-center node.

Residential buildings account for the most damage of the four types of buildings, accounting for 47 percent of the total, followed by industrial, workplace, and commercial buildings, respectively. The total asset value for the four building types is 3963 billion USD while the total AAL is 22.2 million dollars. It is also noticeable that the total damage for the four types of buildings is 18 billion USD in 1/5000-year scenario, residential buildings are significantly vulnerable to extreme flooding in contrast to the three other types of buildings.

The presented method offers the possibility to estimate the damage values for residential, commercial, workplace, and industrial buildings in Shanghai under extreme flooding. It increases the accuracy and details of flood damage estimates for different types of buildings by considerging the direct damage of buildings. The dynamic linkage between the extreme flooding scenarios and the distribution of asset values of the four different types of buildings allows the evaluation of the spatial distribution of flood damages, which would be valuable for individual real eastate managers and also for the city government. 
https://doi.org/10.5194/nhess-2021-382

Preprint. Discussion started: 23 December 2021

(c) Author(s) 2021. CC BY 4.0 License.

(c) (1)

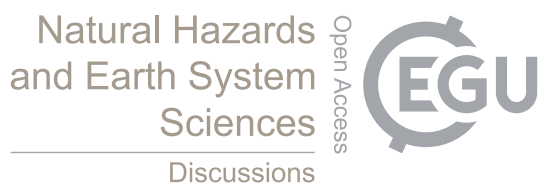

\section{Appendices}

Table A1. Exposed values of different types of buildings under the four flood scenarios in Shanghai (Unit: Billion USD).

\begin{tabular}{lllll}
\hline \multirow{2}{*}{ Building types } & \multicolumn{4}{l}{ Flood scenarios (Return Periods) } \\
\cline { 2 - 5 } & $\mathbf{1 / 2 0 0}$ & $\mathbf{1 / 5 0 0}$ & $\mathbf{1 / 1 0 0 0}$ & $\mathbf{1 / 5 0 0 0}$ \\
\hline Residential building & 22 & 63 & 97 & 217 \\
Commercial building & 3 & 6 & 10 & 25 \\
Office building & 7 & 22 & 35 & 78 \\
Industrial building & 7 & 16 & 25 & 66 \\
Total & 39 & 107 & 166 & 386 \\
\hline
\end{tabular}

395

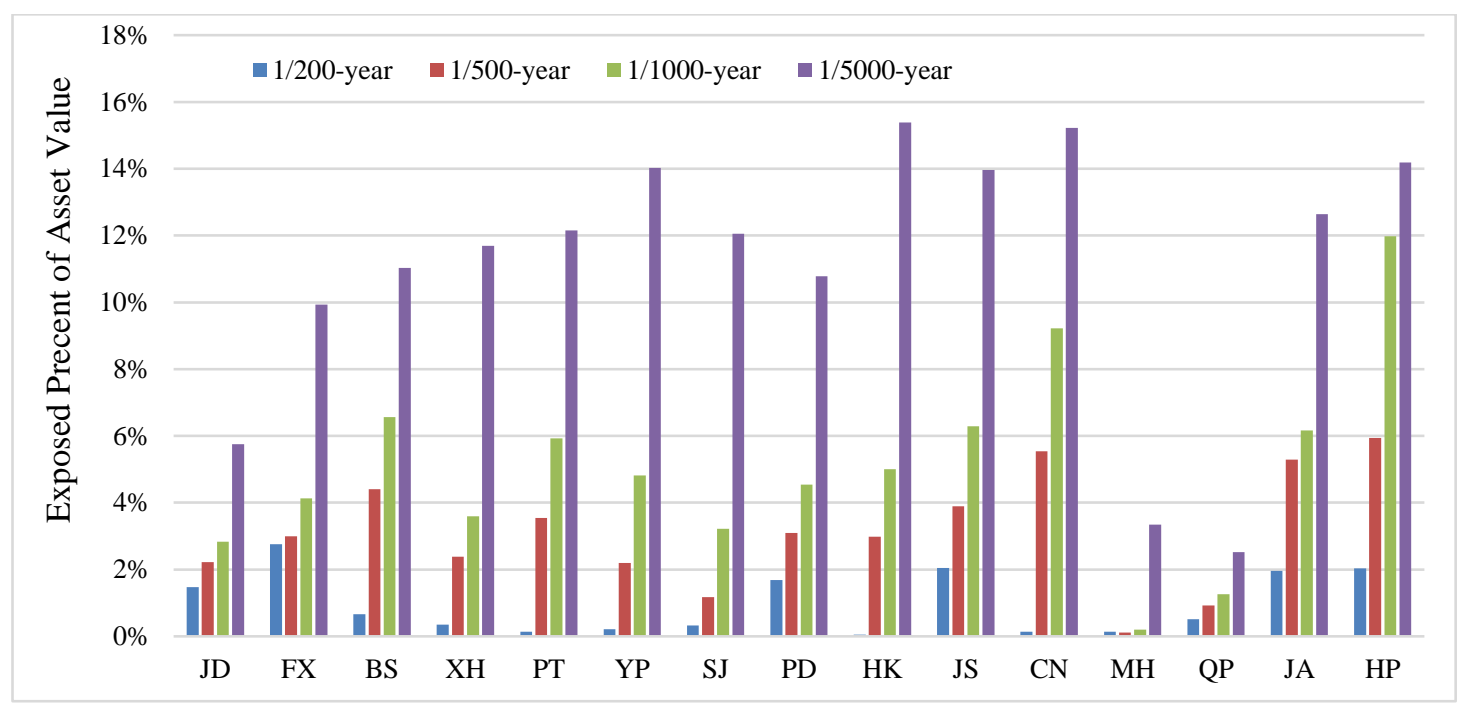

Figure A1. Exposed percentage of residential, commercial, office and industrial buildings to extreme flooding under four return period scenarios in each district. 
https://doi.org/10.5194/nhess-2021-382

Preprint. Discussion started: 23 December 2021

(c) Author(s) 2021. CC BY 4.0 License.

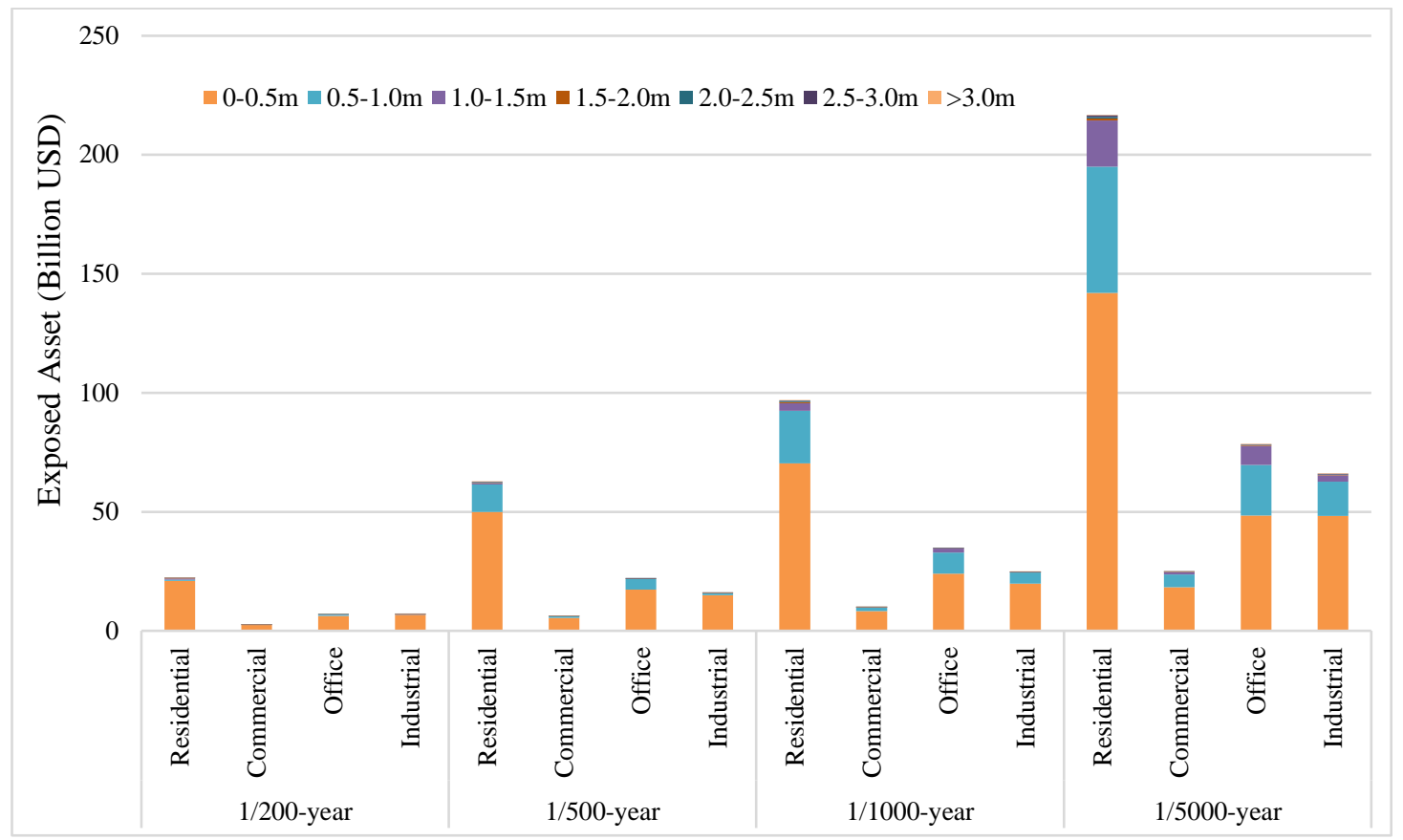

400 Figure A2. The exposed asset categorized by different inundation depths.

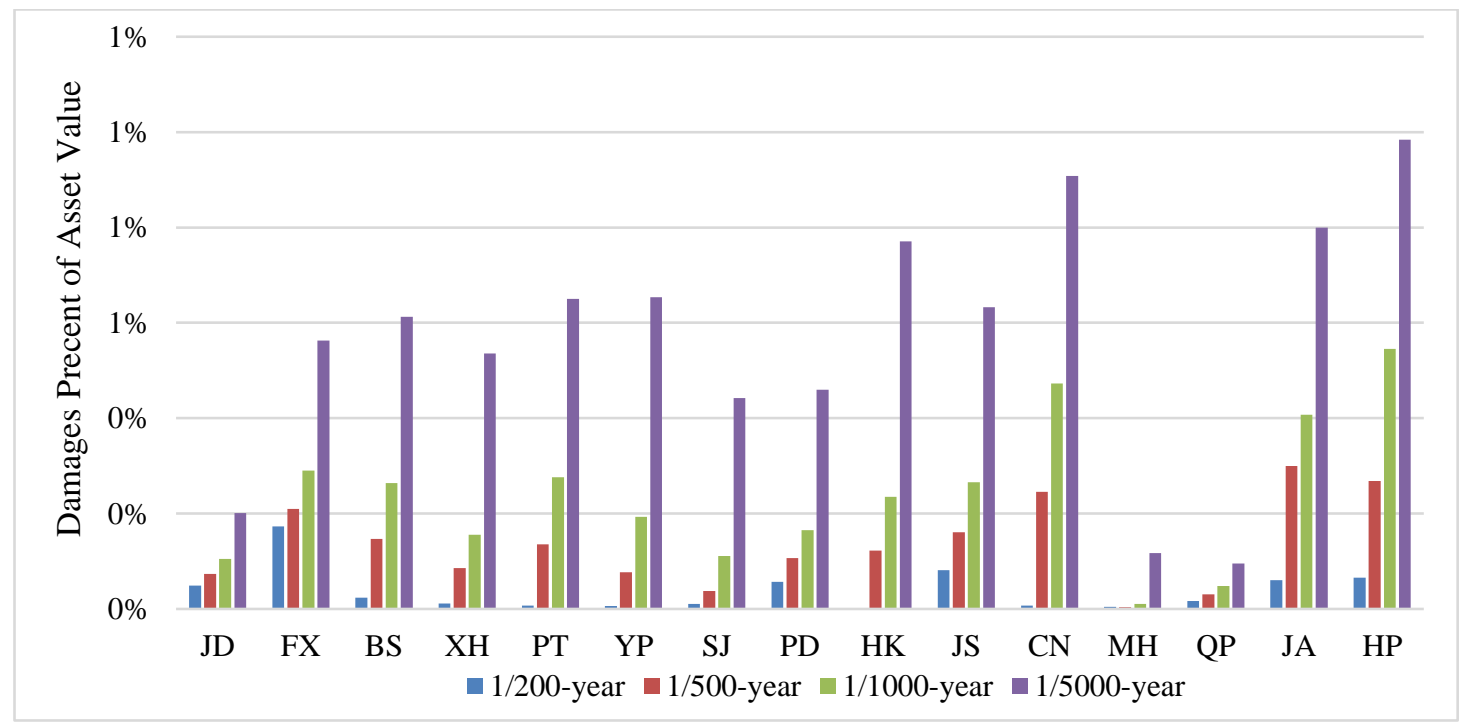

Figure A3. Damage percentages of residential, commercial, office and industrial buildings to extreme flooding under four return period scenarios in each district. 


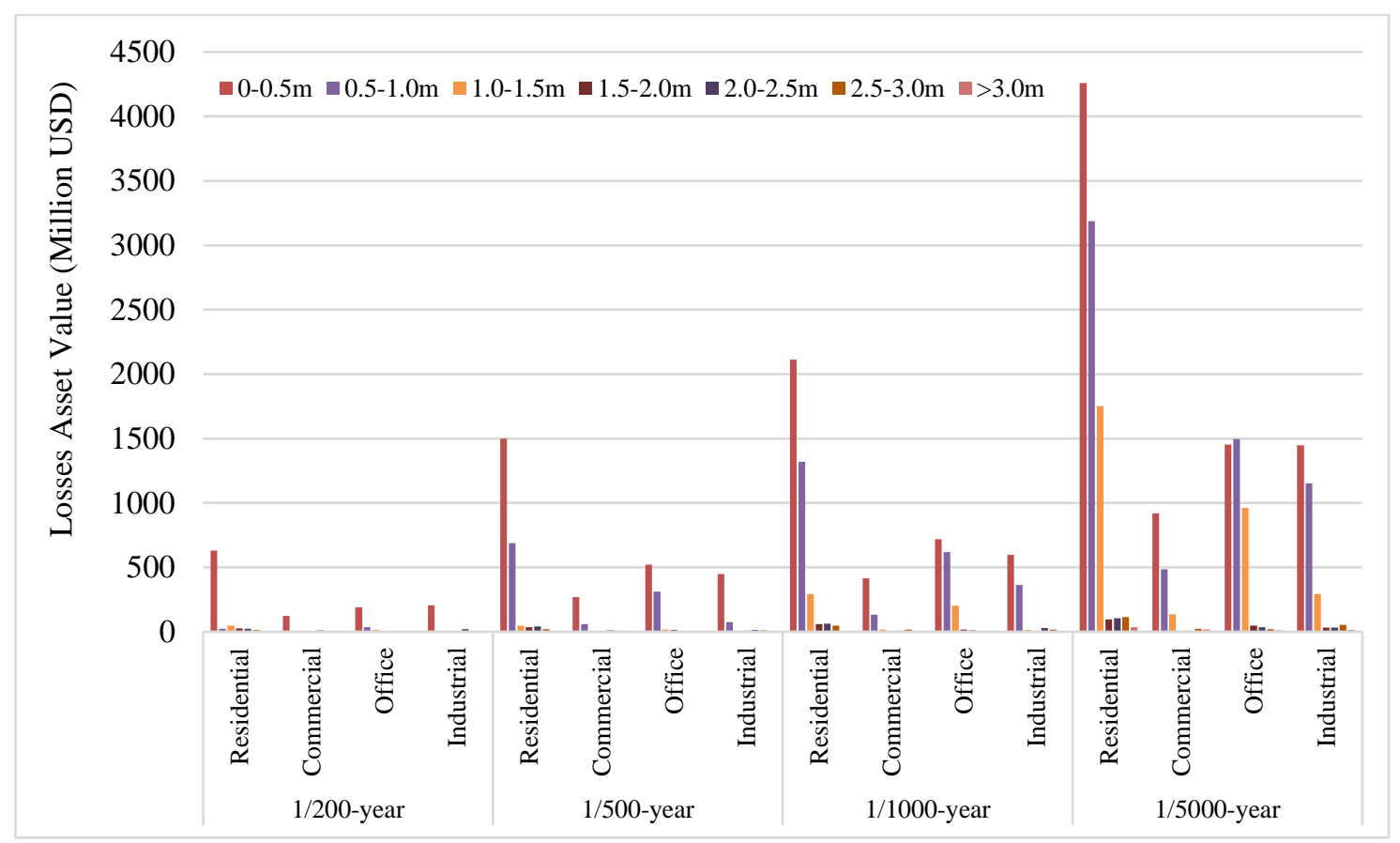

Figure A4. The losses asset in different water depths.

\section{Data availability}

Data used in this study are available from the first author upon request.

\section{Author Contributions}

J.T. analyzed the data, conceived and wrote the paper; J.W. and L.Y. conceived and co-wrote the paper; A.R., M.G. and S.Y. reviewed and improved the analysis and manuscript; M.Z. and L.W. provided the simulation results of the extreme flood scenarios.

\section{Funding}

This research was funded by the National Natural Science Foundation of China (Grant No. 42171080, 41771540, 41871200) and the National Key Research and Development Program of China (Grant No. 2017YFC1503001). 


\section{References}

Arcaids: Construction Cost Handbook 2019 China \& Hang Kong, https://www.arcadis.com/en/knowledgehub/perspectives/asia/research-and-publications/construction-cost-handbook, last access: 20 May 2020.

Baidu Maps: https://map.baidu.com/, last access: 15 May 2018.

Balica, S. F., Wright, N. G., and van der Meulen, F.: A flood vulnerability index for coastal cities and its use in assessing climate change impacts, Natural Hazards, 64, 73-105, 10.1007/s11069-012-0234-1, 2012.

Bryan, B. A., Gao, L., Ye, Y. Q., Sun, X. F., Connor, J. D., Crossman, N. D., Stafford-Smith, M., Wu, J. G., He, C. Y., Yu, D. Y., Liu, Z. F., Li, A., Huang, Q. X., Ren, H., Deng, X. Z., Zheng, H., Niu, J. M., Han, G. D., and Hou, X. Y.: China's response to a national land-system sustainability emergency, Nature, 559, 193-204, 10.1038/s41586-018-0280-2, 2018.

425 Bubeck, P., Dillenardt, L., Alfieri, L., Feyen, L., Thieken, A. H., and Kellermann, P.: Global warming to increase flood risk on European railways, Climatic Change, 155, 19-36, 10.1007/s10584-019-02434-5, 2019.

C40Cities: Staying Afloat: The Urban Response to Sea Level Rise: https://www.c40.org/other/the-future-we-don-t-wantstaying-afloat-the-urban-response-to-sea-level-rise, last access: 14 May 2021.

Chan, F. K. S., Yang, L. E., Scheffran, J., Mitchell, G., Adekola, O., Griffiths, J., Chen, Y. B., Li, G., Lu, X. H., Qi, Y. F., Li, 430 L., Zheng, H., and McDonald, A.: Urban flood risks and emerging challenges in a Chinese delta: The case of the Pearl River Delta, Environ. Sci. Policy, 122, 101-115, 10.1016/j.envsci.2021.04.009, 2021.

Chen, R. S., Zhang, Y. Z., Xu, D., and Liu, M.: Climate Change and Coastal Megacities: Disaster Risk Assessment and Responses in Shanghai City, in: Climate Change, Extreme Events and Disaster Risk Reduction: Towards Sustainable Development Goals, edited by: Mal, S., Singh, R. B., and Huggel, C., Sustainable Development Goals Series, Springer International Publishing Ag, Cham, 203-216, 10.1007/978-3-319-56469-2_14, 2018.

China Standard Press (CSP): The People's Republic of China Current Land Use Classification (GB/T 21010-2017), 2017.

China Standard Press (CSP): The People's Republic of China Code for Real Estate Appraisal (GB/T 50291-2015), 2015.

Chmutina, K., Ganor, T., and Bosher, L.: Role of urban design and planning in disaster risk reduction, Proc. Inst. Civ. Eng.Urban Des. Plan., 167, 125-135, 10.1680/udap.13.00011, 2014.

440 de Ruig, L. T., Haer, T., de Moel, H., Botzen, W. J. W., and Aerts, J.: A micro-scale cost-benefit analysis of building-level flood risk adaptation measures in Los Angeles, Water Resour. Econ., 32, 14, 10.1016/j.wre.2019.100147, 2020.

Du, S. Q., Scussolini, P., Ward, P. J., Zhang, M., Wen, J. H., Wang, L. Y., Koks, E., Diaz-Loaiza, A., Gao, J., Ke, Q., and Aerts, J.: Hard or soft flood adaptation? Advantages of a hybrid strategy for Shanghai, Global Environmental Change, 61, 10, 10.1016/j.gloenvcha.2020.102037, 2020.

445 United States Environmental Protection Agency (EPA), https://www.epa.gov/arc-x/climate-adaptation-and-wetlandprotection, last access: 10 August 2021.

Federal Emergency Management Agency (FEMA), FEMA P-936 Floodfroofing Non-Residential Buildings, 184 pp, 2013. 
Garrote, J., Alvarenga, F., and Díez-Herrero, A.: Quantification of flash flood economic risk using ultra-detailed stage-damage functions and 2-D hydraulic models, Journal of hydrology, 541, 611-625, 10.1016/j.jhydrol.2016.02.006, 2016.

Garschagen, M. and Romero-Lankao, P.: Exploring the relationships between urbanization trends and climate change vulnerability, Climatic Change, 133, 37-52, 10.1007/s10584-013-0812-6, 2015.

Glavan, M., Cvejic, R., Zupanc, V., Knapic, M., and Pintar, M.: Agricultural production and flood control dry detention reservoirs: Example from Lower Savinja Valley, Slovenia, Environ. Sci. Policy, 114, 394-402, 10.1016/j.envsci.2020.09.012, 2020.

455 Gong, S., Li, C., and Yang, S.: Land subsidence and urban flood prevention safety in Shanghai, Hydrogeol Eng Geol, 35, 96$101,2008$.

Gong, S. L. and Yang, S. L.: Effect of Land Subsidence on Urban Flood Prevention Engineering in Shanghai, Scientia Geographic Sinica, 28, 543 - 547, 2008.

Griffiths, J., Chan, F. K. S., Shao, M., Zhu, F. F., and Higgitt, D. L.: Interpretation and application of Sponge City guidelines in China, Philos. Trans. R. Soc. A-Math. Phys. Eng. Sci., 378, 20, 10.1098/rsta.2019.0222, 2020.

Hallegatte, S., Green, C., Nicholls, R. J., and Corfee-Morlot, J.: Future flood losses in major coastal cities, Nature Climate Change, 3, 802-806, 10.1038/nclimate1979, 2013.

Hess, U. and Fischle, R.: Managing Climate Risk with Extreme Weather Insurance, German Society for International Cooperation, Germany, 6, 2019.

465 IPCC: Climate Change 2021: The Physical Science Basis. Contribution of Working Group I to the Sixth Assessment Report of the Intergovernmental Panel on Climate Change, 3949, 2021.

Jongman, B.: Effective adaptation to rising flood risk COMMENT, Nature Communications, 9, 3, 10.1038/s41467-018-04396$1,2018$.

Ke, Q.: Flood risk analysis for metropolitan areas-a case study for Shanghai, Hydraulic Engineering, Delft University of

470 Technology, 193 pp., https://doi.org/10.4233/uuid:61986b2d-72de-45e7-8f2a-bd61c725325d, 2014.

Ke, Q., Jonkman, S. N., van Gelder, P., and Bricker, J. D.: Frequency Analysis of Storm-Surge-Induced Flooding for the Huangpu River in Shanghai, China, Journal of Marine Science and Engineering, 6, 17, 10.3390/jmse6020070, 2018.

Kelman, I. and Spence, R.: An overview of flood actions on buildings, Engineering Geology, 73, 297-309, 10.1016/j.enggeo.2004.01.010, 2004.

475 Liang, P. and Ding, Y. H.: The Long-term Variation of Extreme Heavy Precipitation and Its Link to Urbanization Effects in Shanghai during 1916-2014, Advances in Atmospheric Sciences, 34, 321-334, 10.1007/s00376-016-6120-0, 2017.

McGrath, H., El Ezz, A. A., and Nastev, M. J. N. H.: Probabilistic depth-damage curves for assessment of flood-induced building losses, 97, 1-14, 10.1007/s11069-019-03622-3, 2019.

Middelmann-Fernandes, M. H.: Flood damage estimation beyond stage-damage functions: an Australian example, Journal of

Flood Risk Management, 3, 88-96, 10.1111/j.1753-318X.2009.01058.x, 2010. 
Nguyen, M. T., Sebesvari, Z., Souvignet, M., Bachofer, F., Braun, A., Garschagen, M., Schinkel, U., Yang, L. E., Nguyen, L. H. K., Hochschild, V., Assmann, A., and Hagenlocher, M.: Understanding and assessing flood risk in Vietnam: Current status, persisting gaps, and future directions, Journal of Flood Risk Management, 14, 24, 10.1111/jfr3.12689, 2021.

Park, K. and Won, J. H.: Analysis on distribution characteristics of building use with risk zone classification based on urban flood risk assessment, International Journal of Disaster Risk Reduction, 38, 10, 10.1016/j.ijdrr.2019.101192, 2019.

Paterson, D. L., Wright, H., and Harris, P. N. A.: Health Risks of Flood Disasters, Clin. Infect. Dis., 67, 1450-1454, 10.1093/cid/ciy227, 2018.

Penning-Rowsell, E. C., Yanyan, W., Watkinson, A. R., Jiang, J., and Thorne, C.: Socioeconomic scenarios and flood damage assessment methodologies for the Taihu Basin, China, Journal of Flood Risk Management, 6, 23-32, 10.1111/j.1753318X.2012.01168.x, 2013.

Quan, R. S.: Risk assessment of flood disaster in Shanghai based on spatial-temporal characteristics analysis from 251 to 2000 , Environmental Earth Sciences, 72, 4627-4638, 10.1007/s12665-014-3360-0, 2014.

Shan, X. M., Wen, J. H., Zhang, M., Wang, L. Y., Ke, Q., Li, W. J., Du, S. Q., Shi, Y., Chen, K., Liao, B. G., Li, X. D., and Xu, H.: Scenario-Based Extreme Flood Risk of Residential Buildings and Household Properties in Shanghai, Sustainability, 495 11, 18,doi: 10.3390/su11113202, 2019.

SMBS: Shanghai Statistical Yearbook - 2018, Shanghai: Shanghai Municpal Bureau of Statistics and the National Bureau of Statistics Survey Office in Shanghai, 2018.

Surminski, S. and Oramas-Dorta, D.: Flood insurance schemes and climate adaptation in developing countries, International Journal of Disaster Risk Reduction, 7, 154-164, 10.1016/j.ijdrr.2013.10.005, 2014.

500 Tonkin, J. D., Merritt, D. M., Olden, J. D., Reynolds, L. V., and Lytle, D. A.: Flow regime alteration degrades ecological networks in riparian ecosystems, Nat. Ecol. Evol., 2, 86-93, 10.1038/s41559-017-0379-0, 2018.

United Nations (UN): United Nations World Water Development Report 2020: Water and Climate Change, 2020.

UPLR: SHANGHAI MASTER PLAN 2017-2035, Shanghai Urban Planning and Land Resource Administration Bureau, 2018.

505 Wang, J., Gao, W., Xu, S. Y., and Yu, L. Z.: Evaluation of the combined risk of sea level rise, land subsidence, and storm surges on the coastal areas of Shanghai, China, Climatic Change, 115, 537-558, 10.1007/s10584-012-0468-7, 2012.

Wang, J., Xu, S. Y., Ye, M. W., and Huang, J.: The MIKE Model Application to Overtopping Risk Assessment of Seawalls and Levees in Shanghai, International Journal of Disaster Risk Science, 2, 32-42, 10.1007/s13753-011-0018-3, 2011.

Wang, L., Zhang, M., Wen, J., Chong, Z., Ye, Q., and Ke, Q.: Simulation of extreme compound coastal flooding in Shanghai, 510 Advances in water science, 30 (04), 546-555, 2019.

Wang, Y.: Technical Report: Flood damage assessment in Shanghai city.Flood risk map of Shanghai. IWRH. Beijing., 2001.

Wang, Y. Q. and Zhou, L.: Observed trends in extreme precipitation events in China during 1961-2001 and the associated changes in large-scale circulation, Geophysical Research Letters, 32, 10.1029/2005GL022574, 2005. 
Ward, P. J., de Moel, H., and Aerts, J.: How are flood risk estimates affected by the choice of return-periods?, Natural Hazards

and Earth System Sciences, 11, 3181-3195, 10.5194/nhess-11-3181-2011, 2011.

Woetzel, J., Pinner, D., Samandari, H., Engel, H., Krishnan, M., Boland, B., and Cooper, P.: Can coastal cities turn the tide on rising flood risk, McKinsey Global Institute, 2020a.

Woetzel, J., Pinner, D., Samandari, H., Engel, H., Krishnan, M., Boland, B., and Powis, C. J. M. G. I.: Climate risk and response: Physical hazards and socioeconomic impacts, 22, 2020b.

Wu, J. D., Ye, M. Q., Wang, X., and Koks, E.: Building Asset Value Mapping in Support of Flood Risk Assessments: A Case Study of Shanghai, China, Sustainability, 11, 19, 10.3390/su11040971, 2019.

Wu, X. D., Yu, D. P., Chen, Z. Y., and Wilby, R. L.: An evaluation of the impacts of land surface modification, storm sewer development, and rainfall variation on waterlogging risk in Shanghai, Natural Hazards, 63, 305-323, 10.1007/s11069-0120153-1, 2012.

525 Yang, L., Zhang C, C., and Wambui Ngaruiya, G.: Water supply risks and urban responses under a changing climate: A case study of Hong Kong, Pacific Geographies, 39, 9-15, 2013.

Yang, L., Scheffran, J., Qin, H. P., and You, Q. L.: Climate-related flood risks and urban responses in the Pearl River Delta, China, Regional Environmental Change, 15, 379-391, 10.1007/s10113-014-0651-7, 2015.

Yang, L. E.: Book Review:“Improving Water Supply: To Meet Demand or to Pursue Perfection?”, Water Economics and 530 Policy, 6 (04), 2020.

Yang, L. E., Chan, F. K. S., and Scheffran, J.: Climate change, water management and stakeholder analysis in the Dongjiang River basin in South China, Int. J. Water Resour. Dev., 34, 166-191, 10.1080/07900627.2016.1264294, 2018a.

Yang, L. E., Scheffran, J., Susser, D., Dawson, R., and Chen, Y. D.: Assessment of Flood Losses with Household Responses: Agent-Based Simulation in an Urban Catchment Area, Environ. Model. Assess., 23, 369-388, 10.1007/s10666-018-9597-3, 5352018 b.

Yin, J.: Study on the Risk Assessment of Typhoon Storm Tide in China Coastal Area, Ph.D. thesis, East China Normal University, Shanghai, 2011.

Yin, J., Yu, D. P., Yin, Z. N., Wang, J., and Xu, S. Y.: Modelling the combined impacts of sea-level rise and land subsidence on storm tides induced flooding of the Huangpu River in Shanghai, China, Climatic Change, 119, 919-932, 10.1007/s10584$540 \quad 013-0749-9,2013$.

Yin, J., Yu, D. P., Yin, Z. N., Wang, J., and Xu, S. Y.: Modelling the anthropogenic impacts on fluvial flood risks in a coastal mega-city: A scenario-based case study in Shanghai, China, Landscape and Urban Planning, 136, 144-155, 10.1016/j.landurbplan.2014.12.009, 2015.

Yin, J., Yin, Z. E., Hu, X. M., Xu, S. Y., Wang, J., Li, Z. H., Zhong, H. D., and Gan, F. B.: Multiple scenario analyses 545 forecasting the confounding impacts of sea level rise and tides from storm induced coastal flooding in the city of Shanghai, China, Environmental Earth Sciences, 63, 407-414, 10.1007/s12665-010-0787-9, 2011. 
https://doi.org/10.5194/nhess-2021-382

Preprint. Discussion started: 23 December 2021

(c) Author(s) 2021. CC BY 4.0 License.

(c) (i)

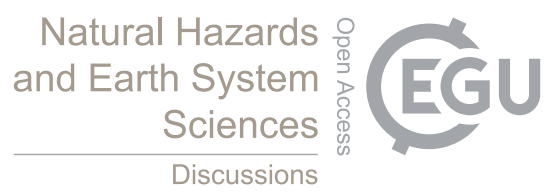

Yu, C., Cheng, X., Hall, J., Evans, E. P., Wang, Y., Hu, C., Wu, H., Wicks, J., Scott, M., and Sun, H.: A GIS-supported impact assessment of the hierarchical flood-defense systems on the plain areas of the Taihu Basin, China, International Journal of Geographical Information Science, 26, 643-665, 2012.

550 Zhou, Z. Z., Liu, S. G., Zhong, G. H., and Cai, Y.: Flood Disaster and Flood Control Measurements in Shanghai, Natural Hazards Review, 18, 8, 10.1061/(asce)nh.1527-6996.0000213, 2017. 